\title{
An Overview of Recent Developments in Biomass Pyrolysis Technologies
}

\author{
M. N. Uddin ${ }^{1}$, Kuaanan Techato ${ }^{2,3}$, Juntakan Taweekun ${ }^{4}$, Md Mofijur Rahman ${ }^{5,6, *}$, \\ M. G. Rasul ${ }^{5}$, T. M. I. Mahlia ${ }^{6}$ and S. M. Ashrafur ${ }^{7}$ iD
}

1 Sustainable Energy Management, IGES, Prince of Songkla University, Hatyai, Songkhla 90110, Thailand; 5910930005@psu.ac.th

2 Environmental Assessment \& Technology for Hazardous Waste Management Research Center, Faculty of Environmental Management, Prince of Songkla University, Hatyai, Songkhla 90110, Thailand; kuaanan.t@psu.ac.th

3 Center of Excellence on Hazardous Substance Management (HSM), Bangkok 10330, Thailand

4 Department of Mechanical Engineering, Faculty of Engineering, Prince of Songkla University, Hatyai, Songkhla 90112, Thailand; jantakan.t@psu.ac.th

5 School of Engineering \& Technology, Central Queensland University, Rockhampton, QLD 4701, Australia; m.rasul@cqu.edu.au

6 Faculty of Engineering and Information Technology, University of Technology, Sydney, NSW 2007, Australia; TMIndra.Mahlia@uts.edu.au

7 Biofuel Engine Research Facility (BERF), Queensland University of Technology, Brisbane, QLD 4000, Australia; s2.rahman@qut.edu.au

* Correspondence: m.rahman@cqu.edu.au; MdMofijur.Rahman@uts.edu.au

Received: 3 October 2018; Accepted: 8 November 2018; Published: 10 November 2018

\begin{abstract}
Biomass is a promising sustainable and renewable energy source, due to its high diversity of sources, and as it is profusely obtainable everywhere in the world. It is the third most important fuel source used to generate electricity and for thermal applications, as $50 \%$ of the global population depends on biomass. The increase in availability and technological developments of recent years allow the use of biomass as a renewable energy source with low levels of emissions and environmental impacts. Biomass energy can be in the forms of biogas, bio-liquid, and bio-solid fuels. It can be used to replace fossil fuels in the power and transportation sectors. This paper critically reviews the facts and prospects of biomass, the pyrolysis process to obtain bio-oil, the impact of different pyrolysis technology (for example, temperature and speed of pyrolysis process), and the impact of various reactors. The paper also discusses different pyrolysis products, their yields, and factors affecting biomass products, including the present status of the pyrolysis process and future challenges. This study concluded that the characteristics of pyrolysis products depend on the biomass used, and what the pyrolysis product, such as bio-oil, can contribute to the local economy. Finally, more research, along with government subsidies and technology transfer, is needed to tackle the future challenges of the development of pyrolysis technology.
\end{abstract}

Keywords: renewable energy; biofuel; environment; technology development

\section{Introduction}

Nowadays, energy usage is prodigious, and a significant key factor for the advancement of a nation, and the scarcity of energy has become an economic threat for the development of nations around the world [1,2]. It is said that "Energy is a critical component of our lives. Without energy, we can't even dream of economic growth. But despite its central role, not everyone has access to modern energy services" [3,4]. Today's energy requirement is increasing in trend, due to population 
growth and ongoing economic and technological advancement around the world [4]. Currently, fossil fuels are the main source of energy because of their high calorific values, good anti-knocking properties, and high heating values; meanwhile, reserves are limited. Therefore, the development of alternative energy resources can lower the depletion of fossil fuel by reducing their consumption [5-7]. On the other hand, the world's heating condition is increasing every day. The atmospheric $\mathrm{CO}_{2}$ level has crossed the risky level that was forecast to happen in another 10 years [8]. Furthermore, the depletion of fossil fuels and extreme change of climate have driven the search for alternative energies and renewable energy sources that can meet the world's energy demand, reduce greenhouse gas emissions, curb pollution, and maintain the planet's temperature at a stable level [9-11].

Among the alternative energy sources, biomass can become a promising sustainable energy source, due to its high diversity and availability [12]. Biomass can be defined as all biodegradable organic material derived from animals, plants, or microorganisms. This definition also includes products, by-products, waste originating in agricultural activities, as well as non-fossil organic waste produced by industrial and municipal waste [13]. Biomass is the third most important source used to generate electricity and thermal applications $[14,15]$. The most common biomass feedstocks are banana peel, rice and coffee husks, sugarcane bagasse, palm oil processing residues, and the waste of animals $[16,17]$. Biomass can be considered as a blend of organic resources and minor amounts of minerals, which also contains carbon, oxygen, hydrogen, nitrogen, sulphur, and chlorine [18].

Different types of energy can be produced through the thermal conversion of biomass, such as combustion, pyrolysis, gasification, fermentation, and anaerobic decomposition. Combustion is a thermochemical process used for the production of heat, which consists of a chemical reaction in which a fuel is oxidised, and a large amount of energy is released in the form of heat (exothermic reaction). Pyrolysis is a thermal decomposition process which takes place in the absence of oxygen $[19,20]$. In combustion and gasification processes, the first step is pyrolysis, followed by total or partial oxidation of primary products. Gasification is the process of generating electricity by applying heat to organic material in the presence of less oxygen. In the fermentation process, organic materials are used to produce alcohol, with the help of yeast, to generate power in automobiles. Anaerobic decomposition is the process of producing biogas, and generates electricity.

Among all the conversion techniques of biomass conversion, the pyrolysis process offers a number of benefits, including less emissions and that all the by-products can be reused. In addition, during the process, pyrolysis produces solid or carbonised products, liquid products (bio-oils, tars, and water) and a gas mixture composed mainly of $\mathrm{CO}_{2}, \mathrm{CO}, \mathrm{H}_{2}$, and $\mathrm{CH}_{4}$ [21-23]. The oil resulting from the pyrolysis of biomass, usually referred to as bio-oil, is a renewable liquid fuel, which is the main advantage over petroleum products. It can be used for the production of various chemical substances [24]. The pyrolysis process has three stages: the dosing and feeding of the raw material, the transformation of the organic mass and, finally, the obtaining and separation of the products (coke, bio-oil, and gas). The factors that influence the distribution of the products are the heating rate, final temperature, composition of the raw material, and pressure [25].

The pyrolysis process has great market potential; in this process, biomass is used as raw material in order to produce energy. Therefore, intense research is taking place around the world to improve this method of energy production. Among the technologies, such as digestion, fermentation, and mechanical conversion, thermo-conversion for producing energy from biomass is relatively newer from a commercial perspective, and gaining more attention because of its technical and strategical advantages. In addition, the production of waste is constantly increasing, and the economic activity linked to it is becoming increasingly important. The elimination or attenuation of environmental problems and obtaining profitability in the process of managing them is a very favourable step. Therefore, pyrolysis could be an alternative means of energy recovery, obtaining different fractions that are also recoverable not only from the energy point of view.

Though the research into pyrolysis technology indicated that pyrolysis is a more promising option to the sustainable development, pyrolysis technology still needs further improvement, and several 
challenges need to be tackled to gain its full potential benefits. Furthermore, several types of research have been carried out recently, focusing on the use of pyrolysis technology, but only a few papers have been analysed and reviewed by the researchers. Thus, the main aims of this study are to present a brief review of the development of pyrolysis technology, including their present status and future challenges, to provide information to the researchers who are interested in pyrolysis technology. A number of studies from highly rated journals in scientific indexes are reviewed, including the most recent publications.

\section{Biomass Pyrolysis}

Biomass is a renewable source for the production of energy, and it is profusely obtainable everywhere in the world $[26,27]$. The sustainable use of biomass energy is an alternative to partially replace the use of fossil fuels and nuclear energy. Rural people in developing countries, representing about $50 \%$ of the global population, depend on biomass energy [9]. Biomass assists the world in meeting greenhouse gas reduction goals $[9,28,29]$. The increase in availability and technological developments of recent years allow the use of biomass as a renewable energy source with low levels of emissions and environmental impacts. Biomass energy can be in the forms of biogas, bio-liquid, and bio-solid fuels. It can be used to replace fossil fuels in power and transportation. It is considered as a renewable energy source because the energy mainly comes from the sun and, also, it needs a short time period to re-grow.

Pyrolysis process is mainly characterised by solid fuel thermal degradation, which involves the rupture of carbon-carbon bonds and the formation of carbon-oxygen bonds. Pyrolysis requires temperatures of up to $400-550^{\circ} \mathrm{C}$, although it can be done at temperatures even higher [30-33]. Figure 1 shows the percentage yield during the pyrolysis of biomass.

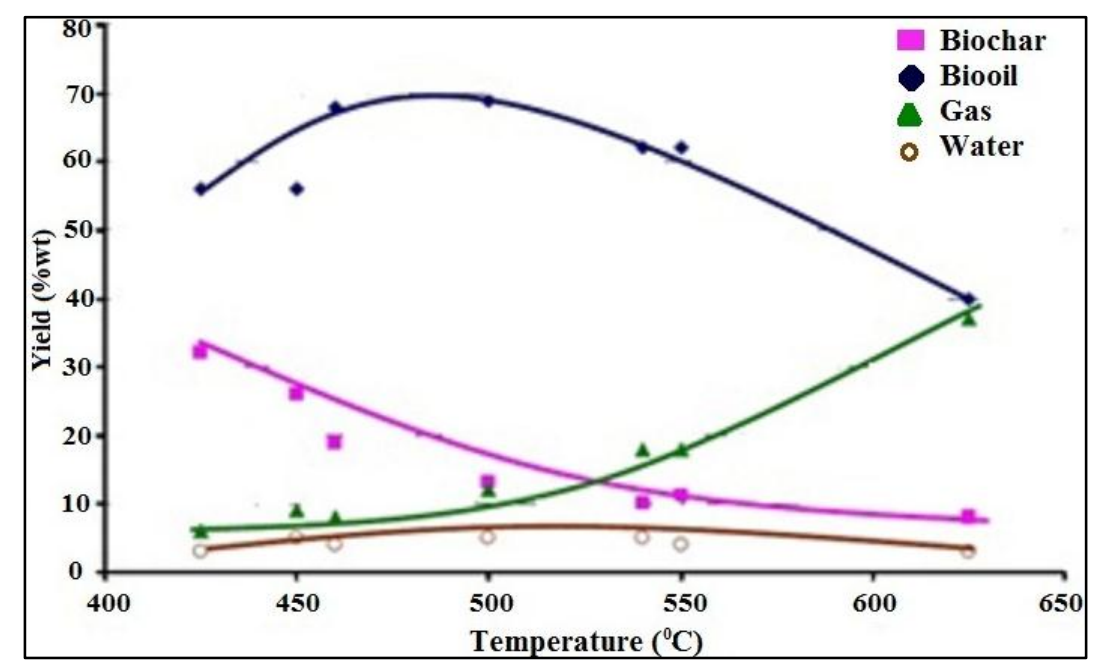

Figure 1. The \% yield of the end products the pyrolysis of biomass [9].

One part of the biomass is reduced to carbon, while the remaining part is oxidised and hydrolysed to carbohydrates, phenols, aldehydes, ketones, alcohols, and carboxylic acids, which combine to form more complex molecules such as esters, polymer products, and others [34-36]. Pyrolysis can be achieved by the complete absence of the oxidising agent. The practice of using air to perform pyrolysis is achieved by feeding air in an amount below stoichiometric; combustion occurs in only a small part of the biomass and, thus, the heat released in the combustion is used to keep the temperature of the reactor constant, while processing the reactions related to pyrolysis [37].

The products formed during pyrolysis, namely, coal fines, gases, acid extract, and bio-oil, have high calorific value, and have had several applications in both the chemical and power generation industries. In ancient Egyptian times, the pyrolysis process was used to generate tar for sealing 
boats [16], and the ancient Egyptians performed wood decontamination by assembling tars and pyrolignous acid for use in their mummifying industry $[38,39]$. Pyrolysis has gained more attention as an effective and practical method in converting biomass into bio-fuel recent years [40]. Pyrolysis is not only part of the combustion and gasification processes, but it is also the first stage of both of these processes. The gas is composed of carbon monoxide, carbon dioxide, and light hydrocarbons. This dark-coloured liquid is called bio-oil and charcoal solid. The yields and quality of the products are influenced by the operating conditions. Pyrolysis receives different denominations depending on the conditions used. In slow pyrolysis or carbonisation, low temperatures and long residence times are employed, favouring the production of charcoal. High temperatures and long residence times favour the formation of gases. Whereas moderate temperatures and low residence time of the gases favour the production of liquids (bio-oil). Figure 2 shows the chemical reaction during the pyrolysis process.

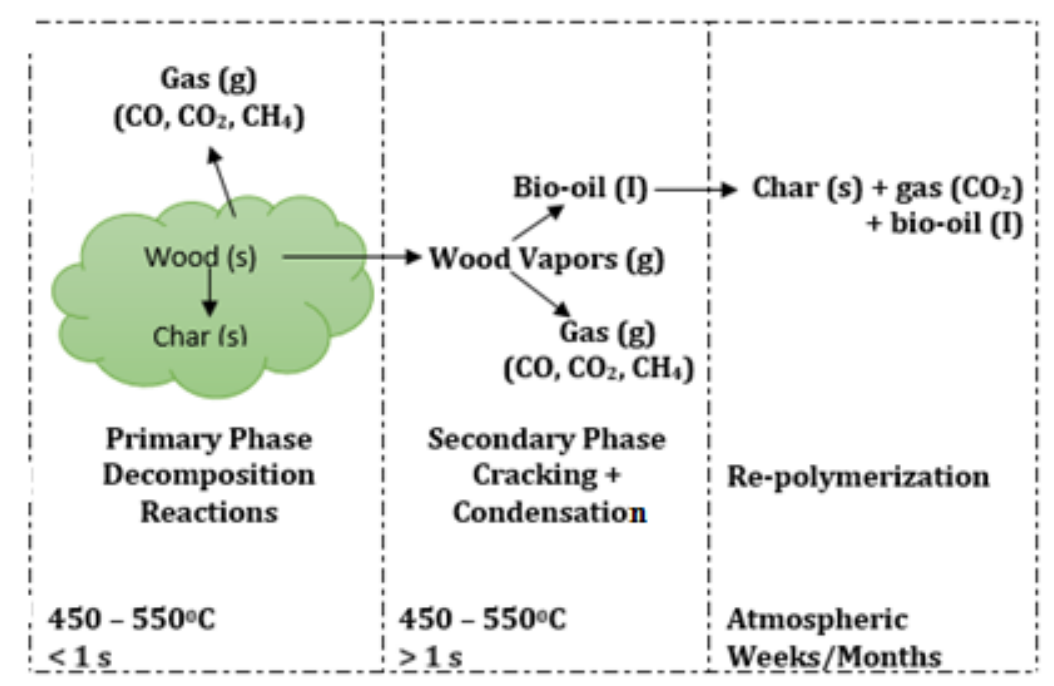

Figure 2. Representation of the reaction paths for wood pyrolysis [41].

\section{Mechanism of Pyrolysis Process}

The biomass pyrolysis can be divided into two categories, such as primary and secondary mechanisms [41]. Figure 3 shows the detailed mechanism of the pyrolysis process. In the primary mechanism, volatile compounds are released, while the chemical bonds within the polymers are broken during biomass heating process [42,43]. Furthermore, rearrangement reactions within the matrix of the residue take place. Some of the volatile compounds which are unstable further undergo additional reactions, which are defined as a secondary mechanism.

The primary mechanism can be described using three different approaches, namely char formation, depolymerisation, and fragmentation. In the char formation process, initially, benzene rings are formed, and these rings combine into a solid residue known as char, which is an aromatic polycyclic structure [44]. During this process, water or incondensable gas is also released [45,46]. In the depolymerisation process, the polymers are broken into monomer units, which reduce the degree of polymerisation. This process continues until the volatile molecules are produced [47]. Finally, in fragmentation, incondensable gas and small chain organic compounds are formed through the linkage of many covalent bonds of the polymer, even within the monomer units [42].

The secondary mechanism consists of cracking, recombination, and others [42,48]. In cracking, lower molecular weight molecules are formed by breaking volatile compounds [49]. By contrast, in the recombination process, volatile compounds combine into high molecular weight compounds, which may or may not be volatile $[43,50]$. In some cases, a secondary mechanism leads to the formation of secondary char $[48,51]$. 


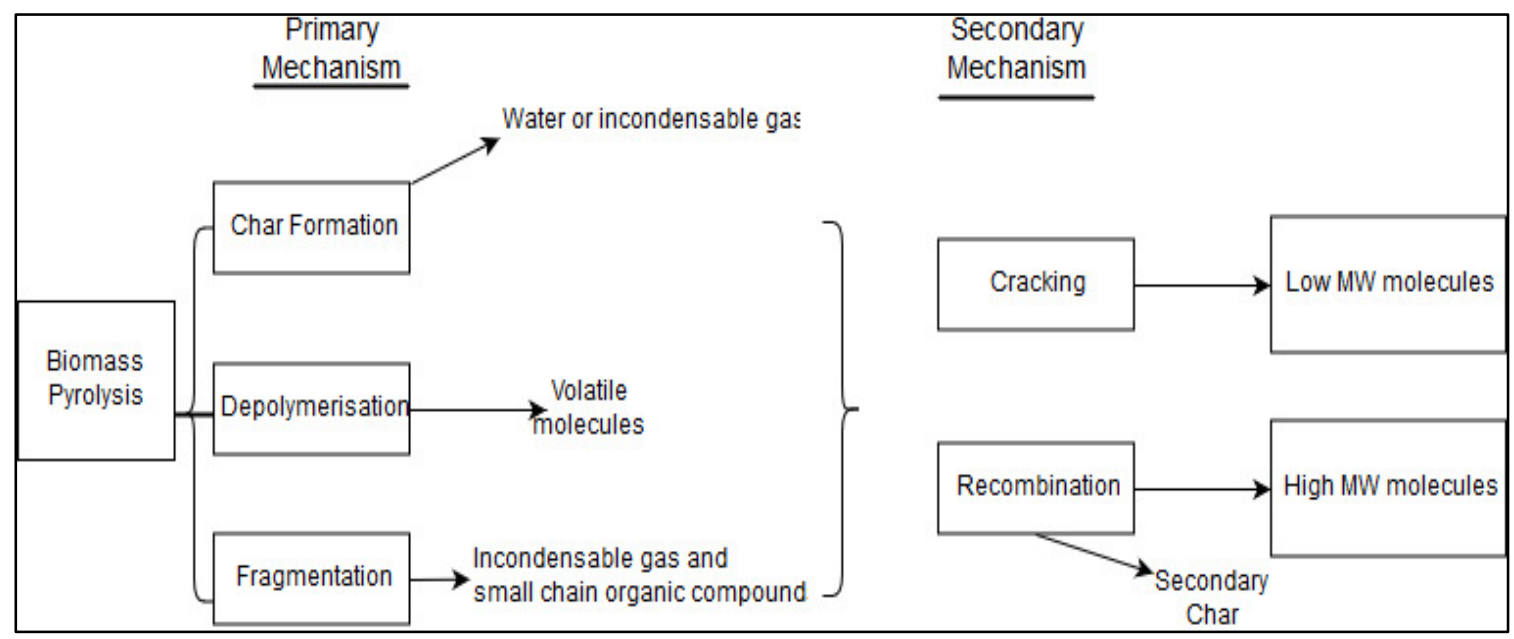

Figure 3. The detailed mechanism of the pyrolysis process.

\section{Sources of Biomass and Their Properties}

Biomass energy is currently recognised as the third largest global energy source. In many developing countries which have significantly large forest and agricultural land, $40-50 \%$ of energy usage is based on biomass. Green plants can directly/indirectly produce biomass using the photosynthesis process, by transforming sunlight into plant material $[29,52]$. The resources of biomass include various natural and derived materials, such as agricultural crops and residues, forest wood and leaf residues, municipal solid wastes (MSW), forest and mill residues, animal residues, and sewage. Agricultural crops and wastage (sugarcane, cassava, and corn) provide carbohydrate and starch. Roughly, the biomass species contain woody biomass, straw, beech wood, seedcakes, bagasse, and municipal solid waste (MSW) [53-59]. The available sources of biomass are shown in Figure 4.

Biomass is a very versatile feedstock in its morphology and physical characteristics. It can be quite wet or dry dense or fluffy, high or low ash containing, small in shape or large, homogeneous or inhomogeneous, and so on. This makes the use of biomass fuels in dedicated gasifier reactors quite difficult and, in most cases, some pre-treatment of the biomass is needed. The feedstocks used for pyrolysis and their physical and chemical properties are more important. The highest bio-char yields are achieved when feedstocks with high lignin content are pyrolysed at moderate temperatures (approx. $500^{\circ} \mathrm{C}$ ). Furthermore, some other indicators of pyrolysis product yields are the ratios of fixed carbon, moisture, volatile matter, and ash content. Generally, biomass containing significant volatile matter offers a large amount of syngas and bio-oil, while fixed carbon raises the production of biochar. Moisture content in biomass influences the heat transfer process, as well as significantly affects product distribution. Tables 1 and 2 show the physical and chemical properties of biomass. Biomass consists of elements such as carbon, hydrogen, oxygen, and nitrogen. Sulphur is present in smaller proportions, and some types of biomass also contain significant portions in inorganic species. The chemicals obtained from co-products and residues can improve the biomass production chains, due to the strategic participation of the chemical industry in the supply of inputs and final products to various economic sectors, for example, agribusiness, petrochemical, automotive, pharmaceutical, cosmetics, civil construction, and so on [60]. 
Table 1. Physical characteristics of biomass [9].

\begin{tabular}{cccccc}
\hline Feedstock & $\begin{array}{c}\text { Density } \\
\left(\mathbf{k g} / \mathbf{m}^{\mathbf{3}} \mathbf{)}\right.\end{array}$ & $\begin{array}{c}\text { Moisture } \\
\text { Content } \mathbf{( \% )}\end{array}$ & $\begin{array}{c}\text { Ash Content } \\
\mathbf{( \% )}\end{array}$ & $\begin{array}{c}\text { Volatile Matter } \\
\mathbf{( \% )}\end{array}$ & $\begin{array}{c}\text { Fixed Carbon } \\
\mathbf{( \% )}\end{array}$ \\
\hline Wood & 380 & 20 & $0.4-1$ & 82 & 17 \\
Bituminous coal & 700 & 11 & $8-11$ & 35 & 45 \\
Wheat straw & 18 & 16 & 4 & 59 & 21 \\
Barley straw & 210 & 30 & 6 & 46 & 18 \\
Pine & 124 & 17 & 0.03 & - & - \\
Polar & 120 & 16.8 & 0.007 & - & - \\
Switchgrass & 108 & $13-15$ & $4.5-5.8$ & - & - \\
\hline
\end{tabular}

Table 2. Chemical characteristics of biomass [9].

\begin{tabular}{cccccc}
\hline Feedstock & Carbon (\%) & Hydrogen (\%) & Oxygen (\%) & Nitrogen (\%) & Ash (\%) \\
\hline Wood & 51.6 & 6.3 & 41.5 & 0.1 & 1 \\
Bituminous coal & 73.1 & 5.5 & 8.7 & 1.4 & 9 \\
Wheat straw & 48.5 & 5.5 & 3.9 & 0.3 & 4 \\
Barley straw & 45.7 & 6.1 & 38.3 & 0.4 & 6 \\
Pine & 45.7 & 7 & 47 & 0.1 & 0.03 \\
Polar & 48.1 & 5.30 & 46.10 & 0.14 & 0.007 \\
Switchgrass & 44.77 & 5.79 & 49.13 & 0.31 & 4.30 \\
\hline
\end{tabular}

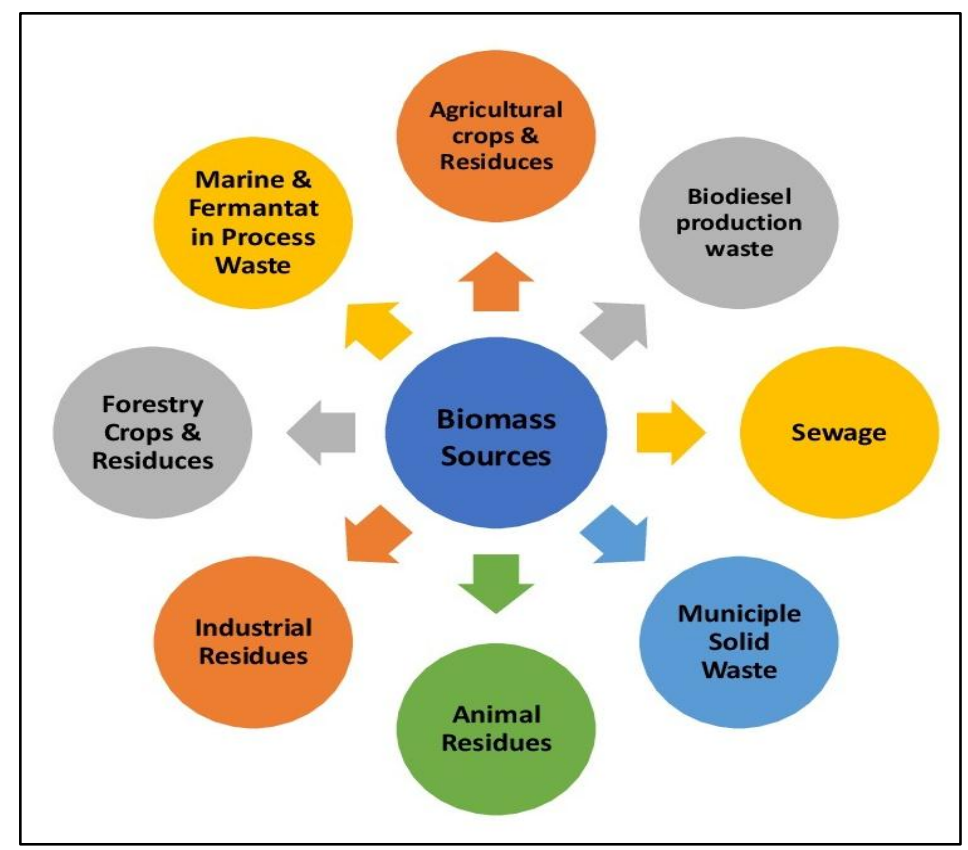

Figure 4. Available sources of biomass [61].

\section{Pyrolysis Technology}

Pyrolysis technology is the decomposition of heated organic matter in the absence of atmospheric oxygen, where heating is controlled by temperature ranges and provides the energy needed to break down the structures of the macromolecules present in biomass [62]. In the process of pyrolysis, biomass degradation occurs through heating, in which the formation of three products occurs: coal, oil, and pyrolytic gas, and, depending on the conditions in the reactor, one of these products can be maximised $[63,64]$. Currently, there are basically three pyrolysis processes in the world: slow pyrolysis, fast pyrolysis, and ultrafast pyrolysis. Biomass is first put into the reactor feed system, usually an endless screw. Then, the biomass enters the reactor and undergoes thermal degradation. Any gas that 
does not condense and has no energetic ends returns to the process and is used as entrainment gas in the reactor.

\subsection{Slow Pyrolysis}

Slow or conventional pyrolysis consists of systems known as "charcoal" or continuous systems, with slow biomass heating above $400{ }^{\circ} \mathrm{C}$ in the absence of oxygen [65]. In this process, the biomass is pyrolysed with low heating rates, around 5 to $7{ }^{\circ} \mathrm{C} /$ minimum, where the liquid and gaseous products are minimal, and the coal production is maximised $[66,67]$. Slow pyrolysis of wood, with a $24 \mathrm{~h}$ endurance, was a very common technology in industries until the early 1900s, where coal, acetic acid, methanol, and ethanol were obtained from wood [68,69]. Slow pyrolysis is characterised by small heating rates and a maximum temperature range of around $600{ }^{\circ} \mathrm{C}$, and the biomass time in the reactor is between 5 and $30 \mathrm{~min}$. The main products are bio-oil, coal, and gases [68].

\subsection{Rapid Pyrolysis}

Rapid pyrolysis is a promising method for conversion of biomass into a liquid product. The produced pyrolysis oil (bio-oil) is an intermediate dense energy fuel, which is possible to upgrade to hydrocarbons in diesel and gasoline [70]. In rapid pyrolysis, the biomass decomposes very quickly, generating mainly vapours and aerosols, and a small amount of coal and gas. After cooling and condensation, a homogeneous mobile dark brown liquid is formed, which has a calorific value corresponding to half of the conventional fuel oil [71]. Rapid pyrolysis technology is used globally, in large scale, for the production of liquids (bio-oils), and there is a lot of interest regarding this technology among biofuel researchers. Several reactors are used in the rapid pyrolysis process. Among them are the dragged-flow reactor, vacuum furnace reactor, vortex reactor, rotary reactor, bubbling fluidised bed reactor, and others; many researchers have contributed in the field of pyrolysis using one of these reactors [67].

\subsection{Ultrafast Pyrolysis}

The ultrafast pyrolysis has, as its main characteristics, very high heating rates and very low residence time of the biomass in the reactor. These characteristics favour the production of vapours, and make the process very similar to gasification. Due to the high heating rate, where biomass residence times are only a few seconds, reactors are needed to meet these heating needs [67]. These reactors have a fluidised bed and are flow-dragged. The fluidised bed reactor is used in the execution of multiphase chemical reactions, where a catalyst, usually sand, is used, working the same as with a fluid inside [72,73]. According to Laird et al. [65], ultrafast pyrolysis for coal production involves heating the biomass, under moderate to high pressure, in a reactor. In this particular case, the coal yield reaches $60 \%$, and is volatile (bio-oil and synthesis gas) to $40 \%$; this technology is more likely to use heat recovery equipment. Table 3 , below, demonstrates some operating parameters of the three types of pyrolysis process [72,73].

Table 3. Operating parameters of different pyrolysis processes.

\begin{tabular}{cccccccc}
\hline Process & Time (s) & Rate (K/s) & Size (mm) & Temp. (K) & Oil Yield & $\begin{array}{c}\text { Char } \\
\text { Yield }\end{array}$ & Gas Yield \\
\hline Slow & $450-550$ & $0.1-1$ & $5-50$ & $550-950$ & 30 & 35 & 35 \\
Fast & $0.5-10$ & $10-200$ & $<1$ & $850-1250$ & 50 & 20 & 30 \\
Flash & $<0.5$ & $>1000$ & $<0.2$ & $1050-1300$ & 75 & 12 & 13 \\
\hline
\end{tabular}

\subsection{Flash Pyrolysis}

This process is also known as fast pyrolysis, due to the high speed of the process. However, in this process, not only kinetics play an important role, but heat and mass transfer processes, such as phase 
change phenomena, are also important. In this process, the biomass decomposes to generate mainly vapours, aerosols, and a certain amount of coke. After cooling and condensation, a dark brown liquid (bio-oil) is formed, with a calorific value that is half the value corresponding to that of diesel. Unlike traditional processes, this is an advanced process with carefully controlled parameters to obtain high liquid yields [74]. In order to carry out this process, the following must be observed: (a) subjecting the biomass particles to an optimum temperature so that they react, and (b) minimising their exposure to low intermediate temperatures that stimulate coke formation. One method to achieve these objectives is to use small particles, for example, those that are present in fluidised bed processes (a fluidised bed is a packed bed with a fine-grained solid). Another possibility is to transfer heat quickly, only to the surface of the particles that are in contact with the heat source, which is applied in ablation processes [75,76].

\section{The Products of Pyrolysis Process}

The pyrolysis of biomass produces three primary products, namely char, permanent gases, and vapours which condense to a viscous liquid (dark brown in colour) at ambient temperature. Biomass pyrolysis product yields can be improved as follows: (1) charcoal-less temperature and lower heating rate procedure, (2) liquid products-lower temperature but higher heating rate procedure, and (3) fuel gas-higher temperature and lower heating rate procedure. Table 4 shows the pyrolysis processes at different temperatures.

Table 4. Pyrolysis processes at different temperature.

\begin{tabular}{ccc}
\hline Condition & \multicolumn{1}{c}{ Processes } & Products \\
\hline$<350{ }^{\circ} \mathrm{C}$ & $\begin{array}{c}\text { Free radical formation, water elimination, } \\
\text { and depolymerisation }\end{array}$ & $\begin{array}{c}\text { Formation of carbonyl and carboxyl, } \\
\text { the evolution of } \mathrm{CO} \text { and } \mathrm{CO}_{2} \text {, and mainly a } \\
\text { charred residue }\end{array}$ \\
\hline $350-450{ }^{\circ} \mathrm{C}$ & $\begin{array}{c}\text { The split of glycosidic connections of } \\
\text { polysaccharide by substitution }\end{array}$ & $\begin{array}{c}\text { A combination of levoglucosan, anhydrides, } \\
\text { and oligosaccharides as a tar segment }\end{array}$ \\
\hline $450-500^{\circ} \mathrm{C}$ & $\begin{array}{c}\text { Dehydration, rearrangement, and fission of } \\
\text { sugar units }\end{array}$ & Formation of carbonyl compounds \\
\hline$>500{ }^{\circ} \mathrm{C}$ & A combination of all the above processes & A combination of all the above products \\
\hline Condensation & Unsaturated products shrink and split to & $\begin{array}{c}\text { A highly reactive char remainder } \\
\text { the char }\end{array}$ \\
\hline
\end{tabular}

\subsection{Bio-Oil}

Bio-oil, also known as pyrolysis oil, crude bio-oil, pyrolytic tar, pyrolignous tar, pyrolignous liquor, wood liquid, wood oil, smoke condensate, and distilled from wood, is a dark brown-coloured liquid, almost black, with a characteristic odour of smoke, and an elemental composition similar to the biomass. It is a complex mixture, containing oxygenated compounds and a high volume of water, which originates from the moisture of the biomass and the reactions. It might also contain some amount of coal particles and dissolved alkali metals from the ash. The composition of the total mixture depends on the type of biomass, process conditions, equipment, and the efficiency in the separation of the coal and the condensation.

The bio-oil can be considered as a micro emulsion, in which the continuous phase is an aqueous solution of the products of cellulose and hemicellulose fragmentation which stabilises the discontinuous phase of the pyrolytic lignin macromolecules [71]. There is a very current and praising demand to convert biomass into liquid fuels in order to use in ships, trains, and aeroplanes, to substitute petrol and diesel $[77,78]$.

Bio-oil is the main product from the pyrolysis process. Several types of research around the world, in order to maximise and improve the quantity and quality of bio-oil produced, are currently 
being carried out. Reactor designs are the primary target of researchers to achieve a better-quality bio-oil. As shown in Figure 5, the bio-oil product has a number of applications: it can be improved to be used as a transport fuel or used as a chemical, and it can also be used in turbines and electric power generation engines, or in boilers to generate heat. In summary, the bio-oil product has many applications and deserves large investments in research.

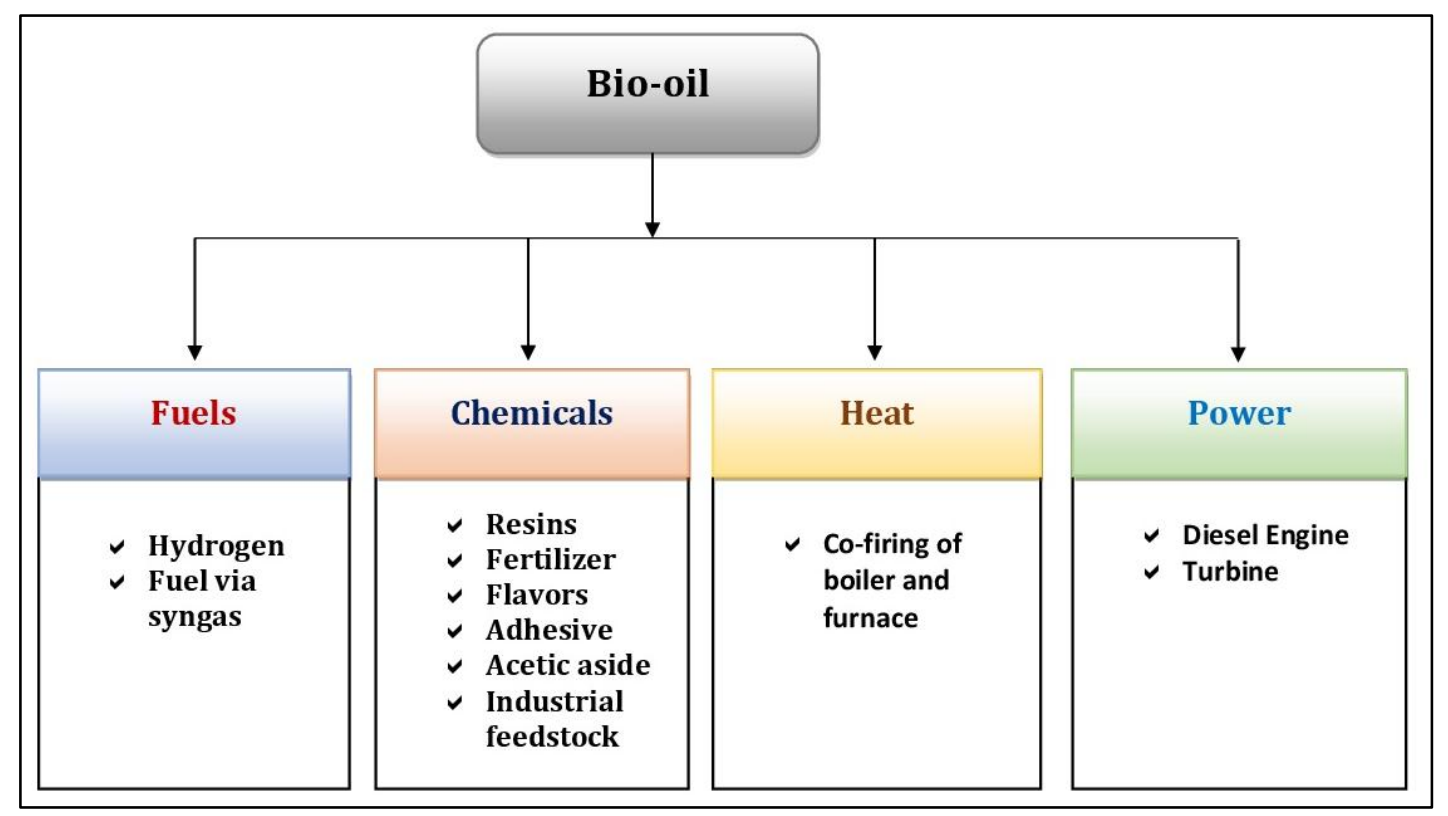

Figure 5. Various applications of pyrolysis bio-oil $[77,78]$.

\subsection{Biochar}

The production of biochar is an emerging technology which can improve countries' food security and mitigate climate change [79]. In the literature, the potential benefits of applying biochar as soil enrichment have been highlighted heavily, addressing issues such as waste management, bioenergy production, increased soil fertility through alteration of soil $\mathrm{pH}$, retention of nutrients through cation adsorption, reduction of emissions of nitrous oxide $\left(\mathrm{N}_{2} \mathrm{O}\right)$, methane $\left(\mathrm{CH}_{4}\right)$, and carbon dioxide $\left(\mathrm{CO}_{2}\right)$, adsorption of organic pollutants, and improvements in productivity [80]. As a promising modifier to soil, biochar attracts the attention of policymakers in developed countries, such as the United States, Japan, Europe, and some developing countries. Sustainable biochar is one of the few technologies that is relatively cheap, widely applicable, and rapidly scalable. These benefits are confirmed by many investigations [79,81,82], including:

- Reduced nitrogen leaching in groundwater

- Possible reduced emissions of nitrous oxide

- Increased cation exchange capacity resulting in better soil fertility

- Moderation of soil acidity

- Greater water retention

- Increase in the number of beneficial soil microbes

\subsection{Syngas}

In slow pyrolysis processes, around $10-35 \%$ of biogas is produced which is similar to char. Syngas produced from biomass pyrolysis can be used as an alternative renewable source of fuel for industrial combustion processes, as well as for internal combustion (IC) engines. In power generation, transportation, and other sectors, gaseous fuel can be used in converted commercial petrol and diesel engines [83], which was quite common between 1901 and 1920 and, after that, due to the availability of 
cheap liquid fuels, the usage of gaseous fuels in IC engines. However, in recent years, as the focus has moved towards renewable fuels for engines, the use of syngas in IC engines has, once again, gained interest [84].

Syngas yield is highly influenced by the pyrolysis temperature, and it is possible to achieve a higher yield in flash pyrolysis with high temperatures. He et al. [85] investigated syngas production in a bench-scale downstream fixed-bed reactor from pyrolysis of MSW over a temperature range of $750-900{ }^{\circ} \mathrm{C}$ [86]. The researchers used calcined dolomite as a catalyst, and reported a $78.87 \%$ gas yield at $900{ }^{\circ} \mathrm{C}$. In another study, Tang and Huang reported $76.64 \%$ syngas yield in a radio frequency plasma pyrolysis reactor [87].

Another factor that greatly influences pyrolysis processes and the resulting product distribution is the reactor temperature. With the increase of pyrolysis temperature, the inner moisture of the biomass evaporates first, followed by thermal degradation and devolatilisation of the dried particle portion. Simultaneously, tar is produced, and volatile species are slowly released from the particles' surface, which then undergoes a series of secondary reactions, such as decarboxylation, dehydrogenation, deoxygenation, and cracking, to form components of syngas. Thus, higher temperatures favour tar decomposition and the thermal cracking of tar to increase the proportion of syngas, which reduces oil and char yields [85]. Some researchers have also reported that when the reactor temperature is increased, the syngas flow rate also increases; however, this lasts for a short time, and then dramatically reduces [88].

Syngas mainly consists of hydrogen $\left(\mathrm{H}_{2}\right)$ and carbon monoxide (CO). It may also contain a small volume of nitrogen $\left(\mathrm{N}_{2}\right)$, water, carbon dioxide $\left(\mathrm{CO}_{2}\right)$, hydrocarbons such as $\mathrm{C}_{2} \mathrm{H}_{4}, \mathrm{CH}_{4}, \mathrm{C}_{2} \mathrm{H}_{6}$, ash, tar, and so on, which depend on biomass feedstock and pyrolysis conditions [89]. These components are obtained during several endothermic reactions at high pyrolysis temperatures.

\section{Reactors Employed in the Pyrolysis Process}

The heart of the pyrolysis process is the reactor. This is the place where all reactions occur [90-93]. However, to perform flash pyrolysis, it is necessary to have special reactors. For this process, an oxygen-free atmosphere is required in the reactor, and a temperature range between 475 and $550{ }^{\circ} \mathrm{C}$. When the gas flows through the bed, the solid behaves like a liquid [94,95].

The reactor is at the core of any sort of pyrolysis procedure that has been the content of invention, significant research, and advancement, to expand the indispensable physiognomies [96-98]. In the beginning, the developers of the pyrolysis reactor presumed that a minor biomass particle size and very short residence time could obtain prominent bio-oil yields, but further research has found divergent consequences. Component part size and vapour residence time have a slight impact on bio-oil yield, while the parameters significantly trace bio-oil composition $[99,100]$. The pyrolytic reactor is undoubtedly the most important equipment in the pyrolysis process. Currently, several types of reactors have been designed, most with the aim of maximising the main product of pyrolysis, the bio-oil. There are many pyrolytic reactors used lately, the main ones being those of fluidised bed (bubbling and circulating). Besides these, we also find the fixed bed, jet bed, rotary cylinder, cyclonic reactor, rotary cone, and others. The reactors can be classified into two general systems, either a batch system or a continuous system (continuous flow of biomass occurs, and continuous collection of the products generated). Table 5 shows the comparison of different pyrolysis reactors. The summary of previous research using different reactors and outcomes is listed in Table 6. 
Table 5. Comparison of various biomass pyrolysis reactors based on overall performance and efficiency [96].

\begin{tabular}{|c|c|c|c|c|c|c|c|}
\hline Pyrolyser & Status (units) & $\begin{array}{c}\text { Bio-Oil } \\
\text { Yield (wt \%) }\end{array}$ & $\begin{array}{l}\text { Operational } \\
\text { Complexity }\end{array}$ & $\begin{array}{l}\text { Particle } \\
\text { Size }\end{array}$ & $\begin{array}{l}\text { Biomass } \\
\text { Variability }\end{array}$ & Scale-Up & $\begin{array}{c}\text { The Inert Gas } \\
\text { Flow Rate }\end{array}$ \\
\hline Fixed bed & $\begin{array}{l}\text { Pilot (single), } \\
\text { lab (multiple) }\end{array}$ & 75 & Medium & Large & High & Hard & Low \\
\hline Fluidised bed & $\begin{array}{c}\text { Demo } \\
\text { (multiple), } \\
\text { lab (multiple) }\end{array}$ & 75 & Medium & Small & Low & Easy & High \\
\hline $\begin{array}{l}\text { Recirculating } \\
\text { bed }\end{array}$ & $\begin{array}{l}\text { Pilot (multiple), } \\
\text { lab (multiple) }\end{array}$ & 75 & High & Medium & Low & Hard & High \\
\hline Rotating cone & Demo (single) & 70 & Medium & Medium & High & Medium & Low \\
\hline Ablative & $\begin{array}{l}\text { Pilot (single), } \\
\text { lab (multiple) }\end{array}$ & 75 & High & Large & High & Hard & Low \\
\hline $\begin{array}{l}\text { Screw / auger } \\
\text { reactor }\end{array}$ & $\begin{array}{l}\text { Pilot (multiple), } \\
\text { lab (multiple) }\end{array}$ & 70 & Low & Medium & High & Easy & Low \\
\hline Vacuum & $\begin{array}{l}\text { Pilot (single), } \\
\text { lab (few) }\end{array}$ & 60 & High & Large & Medium & Hard & Low \\
\hline
\end{tabular}

\subsection{Fixed Bed Reactor}

The fixed bed pyrolysis system is simple, reliable, and proven for fuels that are relatively uniform in size and have a low content of coal fines which consist of a reactor with a gas cooling and cleaning system, and it was customarily used to produce charcoal [101,102]. The fixed bed reactors generally function with high carbon preservation, low gas velocity, and low residue conveyed over a long solid residence time. A major problem of fixed bed reactors is the formation of tar, although the recent evolution in thermal and catalytic conversion of tar has given feasible opportunities for confiscating tar $[103,104]$. Figure 6 shows the fixed bed reactor, which is considered simple, and includes the following basic units: drying, granulation, heating, and cooling. In the fixed bed pyrolysis process, the "temperature" ensures that the variables, such as temperature program, heating rates, and residence time in the temperatures, remain within the limits established by the operator and final pyrolysis temperatures between 450 and $750{ }^{\circ} \mathrm{C}$, with heating rates fluctuating between 5 and $100{ }^{\circ} \mathrm{C} \mathrm{min} / \mathrm{min}$ [105].

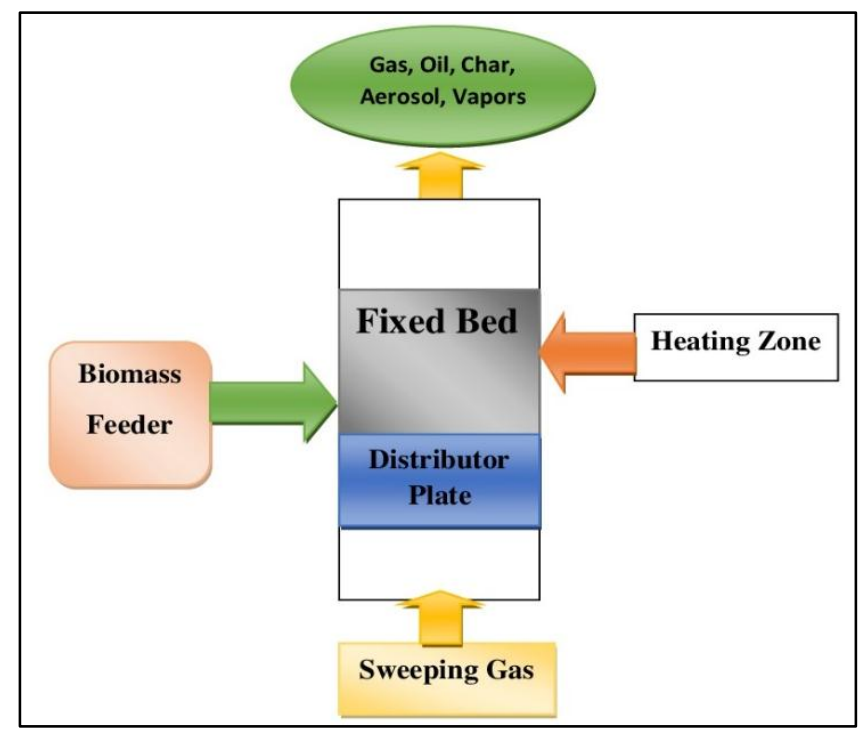

Figure 6. Fixed bed reactor. 


\subsection{Fluidised Bed Reactor}

The fluidised bed reactors (bubbling and circulating) have a well-known technology, and they have a series of industrial applications, where they present themselves as advantageous on a commercial scale, unlike other technologies that are still in the process of improvement [106]. There are several reactors that employ the principle of the fluidised bed, among them, the vortex reactor and the abrasive reactor [105]. Fluidised bed reactors are used in many projects to maximise the liquid product (bio-oil) produced, and several projects demonstrate their real ability to produce good quality bio-oil. As biomass has a very low density, it is common in fluidised bed reactors to use an inert element, usually sand, to give fluid dynamic stability to the process and help biomass heating [107].

The fluidised bed reactor comprises a fluid-solid blend that shows similar properties to the fluid [108]. Fluidised bed reactors seem to be widespread and popular because they offer rapid reaction and heat transfer, a wide and high shallow area of contact between the fluid and solid, and high comparative velocity $[108,109]$. Different types of fluidised bed reactors are available include bubbling fluidised bed reactors and circulating fluidised bed reactors.

\subsubsection{Bubbling Fluidised Beds}

Bubbling fluidised bed gasifier is categorised as having high reaction rates, well-understood technology, simple construction and operation, virtuous temperature control, efficient heat transfer to biomass particles, and it has superior lenience to particle size range [110,111]. It is very prevalent, since it generates high quality bio-oil from a dry source. A significant feature of bubble fluidising bed reactors is they require small biomass particle sizes to attain high biomass heating rates [112].

\subsubsection{Circulating Fluidised Bed (CFB) Reactors}

CFB reactors are comparable with bubbling fluidised bed reactors, and this type of reactor is suitable for large quantities [113]. There are two types of CFB reactors: single circulating and double circulating. The CFB gasifier is considered by all features of the bubbling fluidised bed reactors, along with a higher charge at a lower volume. The CFB pyrolyser is notable for a decent temperature regulator in the reactor $[114,115]$. Figure 7 shows the circulating fluidised bed reactor.

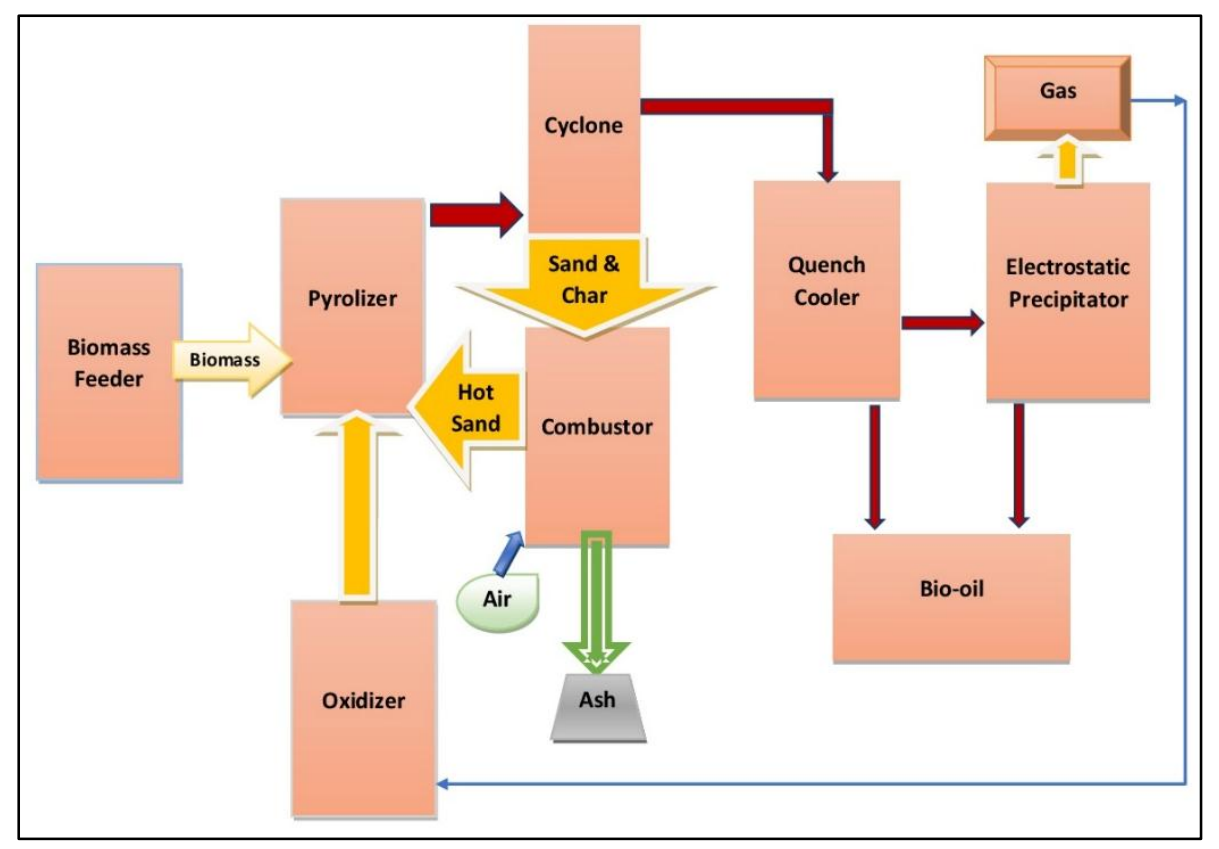

Figure 7. Circulating fluid bed reactor. 


\subsection{Ablative Reactor}

Ablative pyrolysis is primarily dissimilar from fluid bed procedures in the absence of a fluidising gas. Material connected to the wall fundamentally melts, and the residual oil evaporates as pyrolysis vapours. The ablative pyrolysis reactors have good heat transfer with high heating rates and a relatively small contact surface. They also have high energy and cost efficiency, as no heating and cooling of fluidising gases is required, furthermore, they tolerate fixing of condensation units with a small volume in requiring less space at lower costs [116-118].

\subsection{Vacuum Pyrolysis Reactor}

Vacuum reactors represent a sluggish pyrolysis process with lower heat transfer rates conveyed with the fluidised bed technologies. An induction and burner heater is used with molten salts [80]. For this reactor, the vapours formed are quickly detached from the vacuum. This reactor is categorised by lengthier residence time; it is known to produce larger particles than most fast pyrolysis reactors. There is also no requirement for carrier gas, and the process is mechanically complicated; it needs high investment costs. Consistent operation of vacuum pyrolyser entails a superior feedstock input apparatus which discourages latent investors [116-118].

\subsection{Rotating Cone Reactor}

The rotating cone reactor is an innovative reactor for flash pyrolysis with tiny char formation. Biomass ingredients, like rice husks, wood, palm kernel, coffee husk, and so on, can be milled in the rotating cone reactor. There is no big scale of commercial implementation for a rotating cone reactor. Nonetheless, high-speed rotation provokes dynamic mixing of biomass that sequentially proceeds to fast heat transfer $[114,115,119]$. Figure 8 shows the rotating cone reactor.

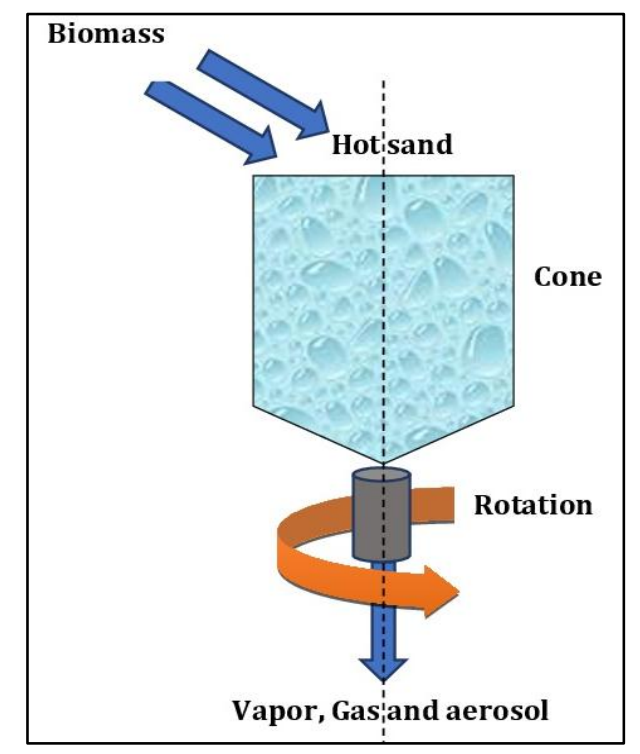

Figure 8. Rotating cone reactor. 
Table 6. Summary of previous researches on biomass conversion.

\begin{tabular}{ccccccc}
\hline \multirow{2}{*}{ Feedstock } & Reactor Type & Temperature & \multicolumn{3}{c}{ Yields (wt \%) } & \multirow{2}{*}{ References } \\
\cline { 3 - 5 } & & & Char & Bio-Oil & Gas & \\
\hline Corn stover & Fluidised bed & $450-600$ & $28-46$ & $35-50$ & $11-14$ & {$[120]$} \\
Rice husk & Fluidised bed & 450 & 29 & 56 & 15 & {$[121]$} \\
Corn cob & Fluidised bed & 500 & 20 & 62 & 17 & {$[121]$} \\
Sugarcane bagasse & Fluidised bed & 500 & 23 & 73 & 4 & {$[122]$} \\
Switchgrass & Fluidised bed & 480 & 13 & 61 & 11 & {$[123]$} \\
Miscanthus & Fluidised bed & 505 & 29 & 51 & 12 & {$[124]$} \\
Wheat straw & Fluidised bed & 550 & 24 & 54 & 24 & {$[125]$} \\
Sunflower hulls & Fluidised bed & 500 & 23 & 57 & 20 & {$[125]$} \\
Rice husk & Fixed bed & $100-500$ & $42-48$ & $28-35$ & - & {$[126]$} \\
Sugarcane bagasse & Vacuum & 530 & 26 & 51 & 22 & {$[127]$} \\
Rice straw & Vacuum & 500 & 35 & 47 & 18 & {$[128]$} \\
Douglas fir & Fixed bed & 500 & 22 & 66 & 8 & {$[129]$} \\
Pine & Vacuum & 500 & 20 & 50 & 30 & {$[130]$} \\
Wood & Ablative & 650 & 6 & 60 & 34 & {$[131]$} \\
Barley straw & Ablative & 549 & 32 & 50 & 12 & {$[128]$} \\
Rice straw & Auger & 500 & 45 & 26 & 13 & {$[120]$} \\
Hardwood & Auger & 500 & 15 & 66 & 18 & {$[132]$} \\
Eucalyptus & Conical spouted & 500 & 18 & 75 & 6 & {$[133]$} \\
Rice husk & Conical spouted & 450 & 26 & 70 & 4 & {$[134]$} \\
Pine chips & Fixed bed & 500 & 31 & 15 & 18 & {$[135]$} \\
Softwood & Auger & 500 & 15 & 69 & 16 & {$[132]$} \\
Olive stone & Rotary kilns & 500 & 26 & 38 & 55 & {$[136]$} \\
\hline
\end{tabular}

\subsection{Auger Reactor}

Auger reactors are used to interchange biomass feedstock over an oxygen-free cylindrical tube. In this reactor, vapour residence time could be altered by fluctuating the heated zone. Auger reactors are getting more consideration from many mid-size industries. Challenges for the auger reactor include stirring parts in the hot precinct and temperature transmission on a large scale [114,115]. Figure 9 shows the Auger pyrolysis reactor.

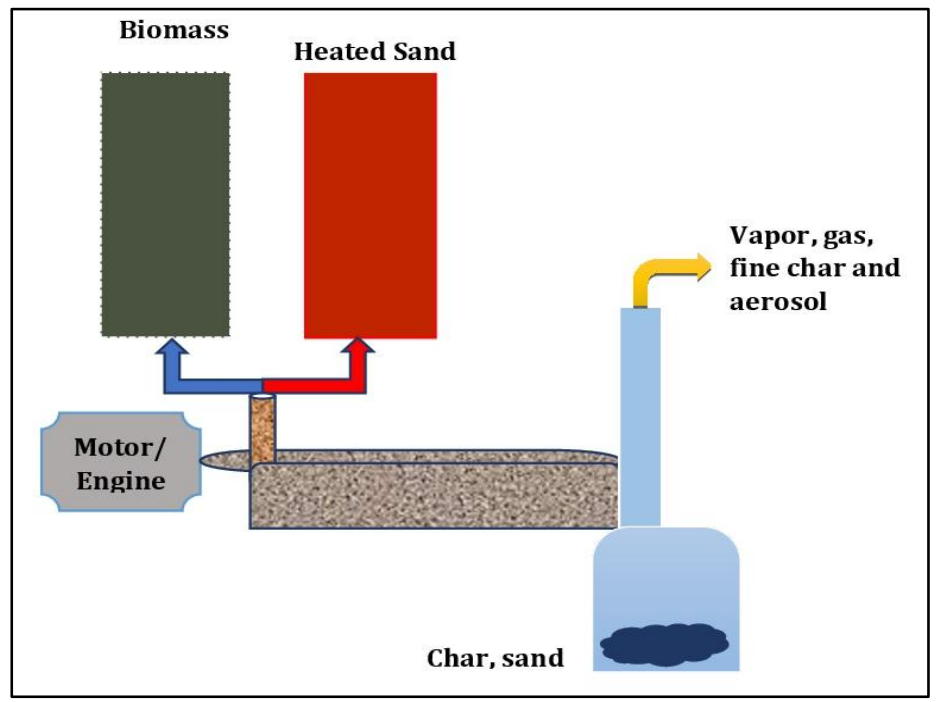

Figure 9. Auger pyrolysis reactor [96].

\section{Current Status of Pyrolysis Technology}

The deteriorating reserves of fossil fuels have posed a great threat and challenge to the quality of life, the world economy, and the environment [137-139]. Biomass pyrolysis possibly will help reduce $\mathrm{CO}_{2}$ and the world's dependence on oil production $[137,140,141]$. These bio-oils have the potential to 
lower $\mathrm{CO}_{2}$ discharges; they are derived from plants which use $\mathrm{CO}_{2}$ for growing. An amalgamation of technologies is required to assimilate reactor design and operational procedure to recover the efficiency of biomass [142,143]. Fast pyrolysis systems process small elements to maximise bio-oil yield, whereas low pyrolysis technologies use wood to produce char chunks $[138,139,141]$. The recognition of the environmental matters are allied with the use of carbonisation technologies and the technical difficulties of operating fast pyrolysis reactors. Intermediate pyrolysis reactors propose prospects for the extensive balanced production of bio-oil and char [144,145]. Presently, the foremost interests in pyrolysis technology are for $\mathrm{CO}_{2}$ mitigation, electricity generation from biomass, and energy independence. The pyrolysis technologies can be considered as slow, intermediate, fast, and flash pyrolysis [146-149] but, then again, the most frequently used systems, meanwhile, are the fast and slow pyrolysis processes. Biochar is the key product of the slow pyrolysis, and transpires with moderate temperature, longer residence time, and small heating system rate [150]. Dissimilarly, bio-oil is the key product of fast pyrolysis which formed with a fast heating rate within short residence time [151,152].

Fast pyrolysis produces a higher quality and quantity of bio-oil than the slow pyrolysis [76,153]. It is expected that environmental and economic performance will increase the effectiveness of the pyrolysis process. Various actions are needed to overcome the technical challenges, including plummeting parasitic energy losses, improving pyrolysis reactor outlines, improving feedstock logistics, and enhancing biomass heating rate [9]. Biomass feedstocks are most important to increase the pyrolysis products on a large scale $[154,155]$. This can be attained by producing energy-condensed products from biomass. Accumulation of metal and ash in reactor bed materials impedes pyrolysis which can reduce bio-oil yields [156,157]. Controlling pyrolysis temperature and heating rate, and using smaller particle sizes can reduce accumulation [158-160]. Recently, a study revealed that an ablative reactor can convert entire wood chips and produce more energy [161,162]. To conclude, cohesive pyrolysis systems that associate gasification or fast pyrolysis are one more important approach for making pyrolysis commercially viable and improving environmental performance [163-167]. Table 7 shows the available pyrolysis plants worldwide.

Table 7. Current pyrolysis plants worldwide [9,168-174].

\begin{tabular}{cccc}
\hline Reactor Technology & Organisation/Location & Capacity $\mathbf{( k g} / \mathbf{h})$ & Desired Product \\
\hline Fixed bed & Bio-alternative, USA & 2000 & Char \\
\hline \multirow{4}{*}{ Bubbling fluidised bed } & THEE & 500 & Gas \\
& Dyna Motive, Canada & 400 & Oil \\
& BEST Energy, Australia & 300 & Oil \\
& Wellman, UK & 250 & Oil \\
& Union Fenosa, Spain & 200 & Oil \\
& Zhejiang University, China & 20 & Oil \\
& RTI, Canada & 20 & Oil \\
& Waterloo University & 3 & Oil \\
& Zhejiang University, China & 3 & Oil \\
\hline \multirow{4}{*}{ Circulating fluidised bed } & Red Arrow, WI; Ensyn & 1700 & Chemicals \\
& Red Arrow, WI; Ensyn & 1500 & Chemicals \\
& Ensyn Engineering & 30 & Oil \\
& VTT, Finland, Ensyn & 20 & Oil \\
\hline \multirow{2}{*}{ Rotating cone } & BTG, Netherlands & 200 & Oil \\
& University Twente & 10 & Oil \\
\hline \multirow{2}{*}{ Vacuum } & Pyrovac, Canada & 350 & Oil \\
& Laval University & 30 & Oil \\
\hline \multirow{2}{*}{ Ablative } & PYTEC, Germany & 250 & Oil \\
& BBC, Canada & $10-15$ & Char \\
\hline Vortex & PYTEC, Germany & 15 & Oil \\
\hline \multirow{2}{*}{ Another type } & Solar energy research Ins. & 30 & Oil \\
& Fortum, Finland & 350 & Oil \\
& University Zaragoza & 100 & Gas \\
& Georgia Tech. Research Ins. & 50 & Oil \\
\hline
\end{tabular}




\section{Future Challenges}

To gain the full potential of biomass pyrolysis technology, such as to enable improved understanding and successful commercialisation, additional research and development are needed. In addition, a couple of issues must be overcome, including the lack of markets for pyrolysis oils and lack of biochar-derived products with well-defined performance characteristics. Also, it is recommended to speed up the improvement and deployment of bio-oil refineries. The improvement of flexible designs for pyrolysis units for producing higher yields of the product is a technical challenge. This review clearly indicates that different pyrolysis technologies have different ranges of product yields. Thus, the selection of pyrolysis technologies, feedstocks, and their operating parameters should be based on the economic trade-offs. However, in addition to the fundamental challenges, a few more important challenges for future biomass pyrolysis research are listed below:

- Understanding the proper working of pyrolysis reactors and processes

- Development of a new reactor that is cost-effective and highly efficient

- Development of catalysts for bio-oil upgrading

- Development of proper solar system reactors

- Post-pyrolysis processing to improve product bio-oil properties

- Understanding the limitations and potential for improvements of the quality of products obtained by biomass pyrolysis

- Development of both fast pyrolysis and bio-oil upgrading, ensuring these are focused on delivering useful and valuable products

For the full implementation of pyrolysis technology, more research is needed to determine designs that will remove oxygen in the gas phase from pyrolysis oil. Pyrolysis technology has the potential to be applied in a vast diversity of situations and, through this process, diversity of products can be obtained. Hence, it is quite difficult to explore a sustainable design for all prospective applications. In addition, balanced financial investments to create new knowledge, technology, and markets for the purpose of building a united vision for the utilisation of pyrolysis technologies is crucial.

\section{Conclusions}

Biomass is a renewable source for the production of energy which is profusely obtainable globally. The sustainable use of biomass energy can be a supplement for fossil fuels and nuclear energy. Biomass consists of elements, such as carbon, hydrogen, oxygen, and nitrogen. Sulphur is present in smaller proportions, and some types of biomass also contain significant portions of inorganic species. There are several types of pyrolysis processes, namely slow, rapid, ultrafast, and flash pyrolysis which can be used to convert the biomass, which depends upon the process used and also depends on the temperature of the pyrolysis. The main products of the pyrolysis of biomass are bio-oil, biochar, and syngas. The physical and chemical properties of these pyrolysis products depend on the quality of biomass. The bio-oil product has a number of applications; it can be improved to be used as a transport fuel or used as a chemical. Reactor designs are the primary target of researchers to achieve a better-quality bio-oil. For example, fluidised bed reactors are used in many projects to maximise the liquid product (bio-oil) produced, and several projects demonstrate their real ability to produce good quality bio-oil. Auger reactors have the potential to be used in small-scale production. Bio-char is considered as a promising addition to the soil. It can be concluded that the development of biomass pyrolysis technology offers more sustainable products compared to the other available technologies. Finally, in order to gain the full potential of biomass pyrolysis technology and address future challenges, additional research and development are needed.

Author Contributions: Original draft preparation, M.N.U.; Supervision, K.T. and J.T.; Review \& Editing, M.M. and T.M.I.M.; Revision, M.G.R. and S.M.A.

Funding: This research received no external funding. 
Conflicts of Interest: The authors declare no conflict of interest.

\section{References}

1. Mofijur, M.; Masjuki, H.; Kalam, M.; Atabani, A.; Shahabuddin, M.; Palash, S.; Hazrat, M. Effect of biodiesel from various feedstocks on combustion characteristics, engine durability and materials compatibility: A review. Renew. Sustain. Energy Rev. 2013, 28, 441-455. [CrossRef]

2. Kusumo, F.; Silitonga, A.S.; Ong, H.C.; Masjuki, H.H.; Mahlia, T.M.I. A comparative study of ultrasound and infrared transesterification of sterculia foetida oil for biodiesel production. Energy Sources Part A Recovery Util. Environ. Effects 2017, 39, 1339-1346. [CrossRef]

3. Islam, M. Challenges of Adopting Strategic Procurement Policies: A Case Study of Infrastructure Development Company Limited. Ph.D. Thesis, BRAC University, Dhaka, Bangladesh, 2017.

4. Bass, S.; Dalal-Clayton, B. Sustainable Development Strategies: A Resource Book; Routledge: Abingdon-on-Thames, UK, 2012.

5. Habibullah, M.; Masjuki, H.; Kalam, M.; Rahman, S.A.; Mofijur, M.; Mobarak, H.; Ashraful, A. Potential of biodiesel as a renewable energy source in Bangladesh. Renew. Sustain. Energy Rev. 2015, 50, 819-834. [CrossRef]

6. Rahman, M.; Rasul, M.; Hassan, N. Study on the tribological characteristics of Australian native first generation and second generation biodiesel fuel. Energies 2017, 10, 55. [CrossRef]

7. Rahman, M.; Rasul, M.; Hassan, N.; Hyde, J. Prospects of biodiesel production from macadamia oil as an alternative fuel for diesel engines. Energies 2016, 9, 403. [CrossRef]

8. Damanik, N.; Ong, H.C.; Tong, C.W.; Mahlia, T.M.I.; Silitonga, A.S. A review on the engine performance and exhaust emission characteristics of diesel engines fueled with biodiesel blends. Environ. Sci. Pollut. Res. 2018, 25, 15307-15325. [CrossRef] [PubMed]

9. Jahirul, M.I.; Rasul, M.G.; Chowdhury, A.A.; Ashwath, N. Biofuels production through biomass pyrolysis-A technological review. Energies 2012, 5, 4952-5001. [CrossRef]

10. Dharma, S.; Masjuki, H.H.; Ong, H.C.; Sebayang, A.H.; Silitonga, A.S.; Kusumo, F.; Mahlia, T.M.I. Optimization of biodiesel production process for mixed jatropha curcas-ceiba pentandra biodiesel using response surface methodology. Energy Convers. Manag. 2016, 115, 178-190. [CrossRef]

11. Kusumo, F.; Silitonga, A.S.; Masjuki, H.H.; Ong, H.C.; Siswantoro, J.; Mahlia, T.M.I. Optimization of transesterification process for ceiba pentandra oil: A comparative study between kernel-based extreme learning machine and artificial neural networks. Energy 2017, 134, 24-34. [CrossRef]

12. Gordon, I.E.; Rothman, L.S.; Hill, C.; Kochanov, R.V.; Tan, Y.; Bernath, P.F.; Birk, M.; Boudon, V.; Campargue, A.; Chance, K. The hitran 2016 molecular spectroscopic database. J. Quant. Spectrosc. Radiat. Transf. 2017, 203, 3-69. [CrossRef]

13. Basu, P. Biomass Gasification and Pyrolysis: Practical Design and Theory; Academic Press: Cambridge, MA, USA, 2010.

14. Basu, P. Combustion and Gasification in Fluidized Beds; CRC Press: Boca Raton, FL, USA, 2006.

15. Forero Núñez, C.A.; Castellanos Contreras, J.U.; Sierra Vargas, F.E. Control de una planta prototipo de gasificación de biomasa mediante redes neuronales. Ingeniería Mecánica, Tecnología y Desarroll 2013, 4, 161-168.

16. Antonio, P.; Alejandra, J.; Martinez Guerrero, P.A.; Cortés Rodriguez, M.F.; Chiviri Torres, N.; Mendoza Geney, L. Uso energético de la biomasa a través del proceso de gasificación. Rev. Investig. 2017, 10, $165-181$.

17. Rincón, J.G.G.; Toscano, J.A.; Gómez, G.G. Análisis exergético de un horno de lecho fijo en la producción de panela. Revista Colombiana De Tecnologias De Avanzada (Rcta) 2017, 1. [CrossRef]

18. Szyszlak-Bargłowicz, J.; Zajacc, G.; Piekarski, W. Energy biomass characteristics of chosen plants. Int. Agrophys. 2012, 26, 175-179. [CrossRef]

19. Castro, A.M.; Carvalho, D.F.; Freire, D.M.G.; Castilho, L.D.R. Economic analysis of the production of amylases and other hydrolases by aspergillus awamori in solid-state fermentation of babassu cake. Enzyme Res. 2010, 2010, 576872. [CrossRef] [PubMed]

20. de Castro, A.M.; de Andréa, T.V.; dos Reis Castilho, L.; Freire, D.M.G. Use of mesophilic fungal amylases produced by solid-state fermentation in the cold hydrolysis of raw babassu cake starch. Appl. Biochem. Biotechnol. 2010, 162, 1612-1625. [CrossRef] [PubMed] 
21. Saletnik, B.; Zagula, G.; Bajcar, M.; Czernicka, M.; Puchalski, C. Biochar and biomass ash as a soil ameliorant: The effect on selected soil properties and yield of giant miscanthus (miscanthus $\times$ giganteus). Energies 2018, 11, 2535. [CrossRef]

22. Chaloupková, V.; Ivanova, T.; Ekrt, O.; Kabutey, A.; Herák, D. Determination of particle size and distribution through image-based macroscopic analysis of the structure of biomass briquettes. Energies 2018, 11, 331. [CrossRef]

23. Castello, D.; Rolli, B.; Kruse, A.; Fiori, L. Supercritical water gasification of biomass in a ceramic reactor: Long-time batch experiments. Energies 2017, 10, 1734. [CrossRef]

24. Valentim, B.; Guedes, A.; Rodrigues, S.; Flores, D. Case study of igneous intrusion effects on coal nitrogen functionalities. Int. J. Coal Geol. 2011, 86, 291-294. [CrossRef]

25. Miandad, R.; Barakat, M.; Aburiazaiza, A.S.; Rehan, M.; Ismail, I.; Nizami, A. Effect of plastic waste types on pyrolysis liquid oil. Int. Biodeterior. Biodegrad. 2017, 119, 239-252. [CrossRef]

26. Ramage, J.; Scurlock, J. “Biomass”. In Renewable Energy-Power for a Sustainable Future; Boyle, G., Ed.; Oxford University Press: Oxford, UK, 1996.

27. Boyle, G. Renewable Energy: Power for a Sustainable Future; Oxford University Press: Oxford, UK, 1996; Volume 2.

28. Muradov, N.Z.; Veziroğlu, T.N. “Green” path from fossil-based to hydrogen economy: An overview of carbon-neutral technologies. Int. J. Hydrogen Energy 2008, 33, 6804-6839. [CrossRef]

29. Pei-dong, Z.; Guomei, J.; Gang, W. Contribution to emission reduction of $\mathrm{CO}_{2}$ and $\mathrm{SO}_{2}$ by household biogas construction in rural china. Renew. Sustain. Energy Rev. 2007, 11, 1903-1912. [CrossRef]

30. López Gómez, F.A.; Rodríguez, O.; Urien, A.; Lobato Ortega, B.; Álvarez Centeno, T.; Alguacil, F.J. Physico-chemical characteristics of the products derived from the thermolysis of waste abies alba mill. Wood. J. Environ. Prot. 2013, 4, 26-30. [CrossRef]

31. Chen, T.; Zhang, Y.; Wang, H.; Lu, W.; Zhou, Z.; Zhang, Y.; Ren, L. Influence of pyrolysis temperature on characteristics and heavy metal adsorptive performance of biochar derived from municipal sewage sludge. Bioresour. Technol. 2014, 164, 47-54. [CrossRef] [PubMed]

32. Oyarzún, B.; Bardow, A.; Gross, J. Integration of process and solvent design towards a novel generation of co2 absorption capture systems. Energy Procedia 2011, 4, 282-290. [CrossRef]

33. Pedroza, M.; Sousa, J.; Vieira, G.; Bezerra, M. Characterization of the products from the pyrolysis of sewage sludge in $1 \mathrm{~kg} / \mathrm{h}$ rotating cylinder reactor. J. Anal. Appl. Pyrolysis 2014, 105, 108-115. [CrossRef]

34. Mesa-Perez, J.; Cortez, L.; Rocha, J.; Brossard-Perez, L.; Olivares-Gómez, E. Unidimensional heat transfer analysis of elephant grass and sugar cane bagasse slow pyrolysis in a fixed bed reactor. Fuel Process. Technol. 2005, 86, 565-575. [CrossRef]

35. Mesa Perez, J.M. Testes em Uma Planta de Pirólise Rápida de Biomassa em Leito Fluidizado: Critérios Para Sua Otimização. Ph.D. Thesis, University of Campinas, Campinas, Brazil, 2004.

36. Sousa, J.F.; Bezerra, M.B.; Almeida, M.B.; Moure, G.T.; Mesa-Perez, J.M.; Caramao, E.B. Characteristics of bio-oil from the fast pyrolysis of elephant grass (pennisetum purpureum schumach) in a fluidized bed reactor. Am. Chem. Sci. J. 2016, 14, 1-10. [CrossRef]

37. Meier, D.; Schoell, S.; Klaubert, H. New ablative pyrolyser in operation in Germany. PyNe Newslett. 2004. Available online: https://www.researchgate.net/publication/237289951_New_Ablative_Pyrolyser_ in_Operation (accessed on 9 November 2018).

38. Mohan, D.; Pittman, C.U.; Steele, P.H. Pyrolysis of wood/biomass for bio-oil: A critical review. Energy Fuels 2006, 20, 848-889. [CrossRef]

39. Demirbaş, A. Biomass resource facilities and biomass conversion processing for fuels and chemicals. Energy Convers. Manag. 2001, 42, 1357-1378. [CrossRef]

40. Demirbaş, A. Partly chemical analysis of liquid fraction of flash pyrolysis products from biomass in the presence of sodium carbonate. Energy Convers. Manag. 2002, 43, 1801-1809. [CrossRef]

41. Venderbosch, R.; Prins, W. Fast pyrolysis technology development. Biofuels Bioprod. Biorefin. 2010, 4, $178-208$. [CrossRef]

42. Van de Velden, M.; Baeyens, J.; Brems, A.; Janssens, B.; Dewil, R. Fundamentals, kinetics and endothermicity of the biomass pyrolysis reaction. Renew. Energy 2010, 35, 232-242. [CrossRef]

43. Hosoya, T.; Kawamoto, H.; Saka, S. Pyrolysis behaviors of wood and its constituent polymers at gasification temperature. J. Anal. Appl. Pyrolysis 2007, 78, 328-336. [CrossRef] 
44. McGrath, T.E.; Chan, W.G.; Hajaligol, M.R. Low temperature mechanism for the formation of polycyclic aromatic hydrocarbons from the pyrolysis of cellulose. J. Anal. Appl. Pyrolysis 2003, 66, 51-70. [CrossRef]

45. Scheirs, J.; Camino, G.; Tumiatti, W. Overview of water evolution during the thermal degradation of cellulose. Eur. Polym. J. 2001, 37, 933-942. [CrossRef]

46. Banyasz, J.; Li, S.; Lyons-Hart, J.; Shafer, K. Gas evolution and the mechanism of cellulose pyrolysis. Fuel 2001, 80, 1757-1763. [CrossRef]

47. Azeez, A.M.; Meier, D.; Odermatt, J. Temperature dependence of fast pyrolysis volatile products from european and african biomasses. J. Anal. Appl. Pyrolysis 2011, 90, 81-92. [CrossRef]

48. Wei, L.; Xu, S.; Zhang, L.; Zhang, H.; Liu, C.; Zhu, H.; Liu, S. Characteristics of fast pyrolysis of biomass in a free fall reactor. Fuel Process. Technol. 2006, 87, 863-871. [CrossRef]

49. Evans, R.J.; Milne, T.A. Molecular characterization of the pyrolysis of biomass. Energy Fuels 1987, 1, $123-137$. [CrossRef]

50. Morf, P.; Hasler, P.; Nussbaumer, T. Mechanisms and kinetics of homogeneous secondary reactions of tar from continuous pyrolysis of wood chips. Fuel 2002, 81, 843-853. [CrossRef]

51. Neves, D.; Thunman, H.; Matos, A.; Tarelho, L.; Gómez-Barea, A. Characterization and prediction of biomass pyrolysis products. Prog. Energy Combust. Sci. 2011, 37, 611-630. [CrossRef]

52. Tilman, D.; Socolow, R.; Foley, J.A.; Hill, J.; Larson, E.; Lynd, L.; Pacala, S.; Reilly, J.; Searchinger, T.; Somerville, C. Beneficial biofuels-The food, energy, and environment trilemma. Science 2009, 325, 270-271. [CrossRef] [PubMed]

53. Demirbas, A. Pyrolysis of ground beech wood in irregular heating rate conditions. J. Anal. Appl. Pyrolysis 2005, 73, 39-43. [CrossRef]

54. Demiral, I.; Şensöz, S. The effects of different catalysts on the pyrolysis of industrial wastes (olive and hazelnut bagasse). Bioresour. Technol. 2008, 99, 8002-8007. [CrossRef] [PubMed]

55. Mohan, D.; Pittman, C.U., Jr.; Bricka, M.; Smith, F.; Yancey, B.; Mohammad, J.; Steele, P.H.; Alexandre-Franco, M.F.; Gómez-Serrano, V.; Gong, H. Sorption of arsenic, cadmium, and lead by chars produced from fast pyrolysis of wood and bark during bio-oil production. J. Colloid Interface Sci. 2007, 310, 57-73. [CrossRef] [PubMed]

56. Aho, A.; Kumar, N.; Eränen, K.; Salmi, T.; Hupa, M.; Murzin, D.Y. Catalytic pyrolysis of woody biomass in a fluidized bed reactor: Influence of the zeolite structure. Fuel 2008, 87, 2493-2501. [CrossRef]

57. Karaosmanoğlu, F.; Tetik, E. Fuel properties of pyrolytic oil of the straw and stalk of rape plant. Renew. Energy 1999, 16, 1090-1093. [CrossRef]

58. Jensen, P.A.; Sander, B.; Dam-Johansen, K. Pretreatment of straw for power production by pyrolysis and char wash. Biomass Bioenergy 2001, 20, 431-446. [CrossRef]

59. Pütün, E.; Uzun, B.B.; Pütün, A.E. Fixed-bed catalytic pyrolysis of cotton-seed cake: Effects of pyrolysis temperature, natural zeolite content and sweeping gas flow rate. Bioresour. Technol. 2006, 97, 701-710. [CrossRef] [PubMed]

60. Popp, J.; Lakner, Z.; Harangi-Rákos, M.; Fári, M. The effect of bioenergy expansion: Food, energy, and environment. Renew. Sustain. Energy Rev. 2014, 32, 559-578. [CrossRef]

61. Zafar, S. Importance of biomass energy. Available online: https://www.bioenergyconsult.com/tag/ importance-of-biomass-energy/ (accessed on 9 November 2018).

62. Diniz, V.; Volesky, B. Biosorption of la, eu and yb using sargassum biomass. Water Res. 2005, 39, $239-247$. [CrossRef] [PubMed]

63. Santos, J.; Nunes, L.; Melo, W.; Araújo, A. Tannery sludge compost amendment rates on soil microbial biomass of two different soils. Eur. J. Soil Boil. 2011, 47, 146-151. [CrossRef]

64. Karlen, D.L. Cellulosic Energy Cropping Systems; John Wiley \& Sons: Hoboken, NJ, USA, 2014.

65. Laird, D.A.; Brown, R.C.; Amonette, J.E.; Lehmann, J. Review of the pyrolysis platform for coproducing bio-oil and biochar. Biofuels Bioprod. Biorefin. 2009, 3, 547-562. [CrossRef]

66. Luengo, C.; Felfli, F.; Bezzon, G. Pirólise e Torrefação de Biomassa. Biomassa Para Energia. Cortez, LAB, Lora, EES, Gómez EO (Organizadores); Editora da Unicamp: Campinas, Brazil, 2008; pp. 333-351.

67. Goyal, H.; Seal, D.; Saxena, R. Bio-fuels from thermochemical conversion of renewable resources: A review. Renew. Sustain. Energy Rev. 2008, 12, 504-517. [CrossRef]

68. Gomes, M.D.S. Produção de Bio-Óleo Através do Processo Termoquímico de Pirólise; Fatec: Araçatuba, Brazil, 2010. 
69. Huber, G.W.; Iborra, S.; Corma, A. Synthesis of transportation fuels from biomass: Chemistry, catalysts, and engineering. Chem. Rev. 2006, 106, 4044-4098. [CrossRef] [PubMed]

70. Strahan, G.D.; Mullen, C.A.; Boateng, A.A. Characterizing biomass fast pyrolysis oils by ${ }^{13} \mathrm{C}$ NMR and chemometric analysis. Energy Fuels 2011, 25, 5452-5461. [CrossRef]

71. Bridgwater, A.V. Review of fast pyrolysis of biomass and product upgrading. Biomass Bioenergy 2012, 38, 68-94. [CrossRef]

72. MOTA, A.M.A.; Lima, A.A.S.; Santos, F.F.P.; Caselli, F.D.T.R.; Viegas, R.A. Pirólise da biomassa lignocelulósica: Uma revisão. Rev. GEINTEC-Gestão Inovação E Tecnol. 2015, 5, 2511-2525. [CrossRef]

73. da Silva Mota, F.D.A.; Viegas, R.A.; da Silva Lima, A.A.; dos Santos, F.F.P.; Caselli, F.D.T.R. Pirólise da biomassa lignocelulósica: Uma revisão pyrolysis of lignocellulose biomass: A review. Rev. GEINTEC 2015, 5, 2511-2525. [CrossRef]

74. Bridgwater, T. Biomass for energy. J. Sci. Food Agric. 2006, 86, 1755-1768. [CrossRef]

75. Bridgwater, A. Principles and practice of biomass fast pyrolysis processes for liquids. J. Anal. Appl. Pyrolysis 1999, 51, 3-22. [CrossRef]

76. Czernik, S.; Bridgwater, A. Overview of applications of biomass fast pyrolysis oil. Energy Fuels 2004, 18, 590-598. [CrossRef]

77. Demirbas, A. The influence of temperature on the yields of compounds existing in bio-oils obtained from biomass samples via pyrolysis. Fuel Process. Technol. 2007, 88, 591-597. [CrossRef]

78. Demirbas, A. Combustion characteristics of different biomass fuels. Prog. Energy Combust. Sci. 2004, 30, 219-230. [CrossRef]

79. Lehmann, J.; Joseph, S. Biochar for Environmental Management: Science, Technology and Implementation; Routledge: Abingdon-on-Thames, UK, 2015.

80. Mašek, O.; Brownsort, P.; Cross, A.; Sohi, S. Influence of production conditions on the yield and environmental stability of biochar. Fuel 2013, 103, 151-155. [CrossRef]

81. Huang, G.; Chen, F.; Wei, D.; Zhang, X.; Chen, G. Biodiesel production by microalgal biotechnology. Appl. Energy 2010, 87, 38-46. [CrossRef]

82. Kanaujia, P.K.; Sharma, Y.; Agrawal, U.; Garg, M. Analytical approaches to characterizing pyrolysis oil from biomass. TrAC Trends Anal. Chem. 2013, 42, 125-136. [CrossRef]

83. Das, L.M.; Gulati, R.; Gupta, P.K. A comparative evaluation of the performance characteristics of a spark ignition engine using hydrogen and compressed natural gas as alternative fuels. Int. J. Hydrog. Energy 2000, 25, 783-793. [CrossRef]

84. Saidur, R.; Jahirul, M.I.; Moutushi, T.Z.; Imtiaz, H.; Masjuki, H.H. Effect of partial substitution of diesel fuel by natural gas on performance parameters of a four-cylinder diesel engine. Proc. Inst. Mech. Eng. Part A J. Power Energy 2007, 221, 1-10. [CrossRef]

85. He, M.; Xiao, B.; Liu, S.; Hu, Z.; Guo, X.; Luo, S.; Yang, F. Syngas production from pyrolysis of municipal solid waste (MSW) with dolomite as downstream catalysts. J. Anal. Appl. Pyrolysis 2010, 87, 181-187. [CrossRef]

86. Kantarelis, E.; Zabaniotou, A. Valorization of cotton stalks by fast pyrolysis and fixed bed air gasification for syngas production as precursor of second generation biofuels and sustainable agriculture. Bioresour. Technol. 2009, 100, 942-947. [CrossRef] [PubMed]

87. Tang, L.; Huang, H. Plasma pyrolysis of biomass for production of syngas and carbon adsorbent. Energy Fuels 2005, 19, 1174-1178. [CrossRef]

88. Ahmed, I.; Gupta, A.K. Syngas yield during pyrolysis and steam gasification of paper. Appl. Energy 2009, 86, 1813-1821. [CrossRef]

89. Fernández, Y.; Menéndez, J.A. Influence of feed characteristics on the microwave-assisted pyrolysis used to produce syngas from biomass wastes. J. Anal. Appl. Pyrolysis 2011, 91, 316-322. [CrossRef]

90. Basu, P. Biomass Gasification, Pyrolysis and Torrefaction: Practical Design and Theory; Academic Press: Cambridge, MA, USA, 2018.

91. Basu, P.; Kaushal, P. Modeling of pyrolysis and gasification of biomass in fluidized beds: A review. Chem. Prod. Process Model. 2009, 4. [CrossRef]

92. Basu, P.; Sadhukhan, A.K.; Gupta, P.; Rao, S.; Dhungana, A.; Acharya, B. An experimental and theoretical investigation on torrefaction of a large wet wood particle. Bioresour. Technol. 2014, 159, 215-222. [CrossRef] [PubMed] 
93. Basu, P.; Acharya, B.; Dutra, A. Gasification in fluidized beds-Present status \& design. In Proceedings of the 20th International Conference on Fluidized Bed Combustion, Xi'an, China, 18-21 May 2009; pp. 97-103.

94. Papadikis, K.; Gu, S.; Bridgwater, A. CFD modelling of the fast pyrolysis of biomass in fluidised bed reactors. Part b: Heat, momentum and mass transport in bubbling fluidised beds. Chem. Eng. Sci. 2009, 64, 1036-1045. [CrossRef]

95. Deo, M.D.; Fletcher, J.V.; Shun, D.; Hanson, F.V.; Oblad, A.G. Modelling the pyrolysis of tar sands in fluidized bed reactors. Fuel 1991, 70, 1271-1276. [CrossRef]

96. Zhang, S.; Yan, Y.; Li, T.; Ren, Z. Upgrading of liquid fuel from the pyrolysis of biomass. Bioresour. Technol. 2005, 96, 545-550. [CrossRef] [PubMed]

97. Bridgwater, A.; Peacocke, G. Fast pyrolysis processes for biomass. Renew. Sustain. Energy Rev. 2000, 4, 1-73. [CrossRef]

98. Lappas, A.; Samolada, M.; Iatridis, D.; Voutetakis, S.; Vasalos, I. Biomass pyrolysis in a circulating fluid bed reactor for the production of fuels and chemicals. Fuel 2002, 81, 2087-2095. [CrossRef]

99. Wang, X.; Kersten, S.R.; Prins, W.; van Swaaij, W.P. Biomass pyrolysis in a fluidized bed reactor. Part 2: Experimental validation of model results. Ind. Eng. Chem. Res. 2005, 44, 8786-8795. [CrossRef]

100. Kersten, S.R.; Wang, X.; Prins, W.; van Swaaij, W.P. Biomass pyrolysis in a fluidized bed reactor. Part 1: Literature review and model simulations. Ind. Eng. Chem. Res. 2005, 44, 8773-8785. [CrossRef]

101. De Filippis, P.; Borgianni, C.; Paolucci, M.; Pochetti, F. Gasification process of cuban bagasse in a two-stage reactor. Biomass Bioenergy 2004, 27, 247-252. [CrossRef]

102. Leung, D.Y.; Yin, X.; Wu, C. A review on the development and commercialization of biomass gasification technologies in china. Renew. Sustain. Energy Rev. 2004, 8, 565-580. [CrossRef]

103. Wang, L.; Weller, C.L.; Jones, D.D.; Hanna, M.A. Contemporary issues in thermal gasification of biomass and its application to electricity and fuel production. Biomass Bioenergy 2008, 32, 573-581. [CrossRef]

104. Chopra, S.; Jain, A. A review of fixed bed gasification systems for biomass. 2007. Available online: https:// ecommons.cornell.edu/bitstream/handle/1813/10671/Invited?sequence=1 (accessed on 9 November 2018).

105. Martini, P.R.R. Conversão Pirolítica de Bagaço Residual da Indústria de Suco de Laranja e Caracterização Química dos Produtos. Ph.D. Thesis, UFSM, Santa Maria, Brazil, 2009.

106. Berton, R.P. Análise Teórica Comparativa de Eficiência Energética de Sistemas Integrados Para Pirólise Rápida de Biomassa. Master's Thesis, University of Campinas, Campinas, Brazil, 2012.

107. Santos, K.G. Aspectos Fundamentais da Pirólise de Biomassa em Leito de Jorro: Fluidodinâmica e Cinética do Processo. Ph.D. Thesis, Federal University of Uberlândia, Uberlândia, Brazil, 2011.

108. Aldaco, R.; Irabien, A.; Luis, P. Fluidized bed reactor for fluoride removal. Chem. Eng. J. 2005, 107, $113-117$. [CrossRef]

109. Rao, M.; Singh, S.; Sodha, M.; Dubey, A.; Shyam, M. Stoichiometric, mass, energy and exergy balance analysis of countercurrent fixed-bed gasification of post-consumer residues. Biomass Bioenergy 2004, 27, 155-171. [CrossRef]

110. Warnecke, R. Gasification of biomass: Comparison of fixed bed and fluidized bed gasifier. Biomass Bioenergy 2000, 18, 489-497. [CrossRef]

111. Radmanesh, R.; Chaouki, J.; Guy, C. Biomass gasification in a bubbling fluidized bed reactor: Experiments and modeling. AIChE J. 2006, 52, 4258-4272. [CrossRef]

112. Sadaka, S.; Boateng, A. Pyrolysis and Bio-Oil, Agriculture and Natural Resources; FSA1052; University of Arkansas: Fayetteville, AK, USA, 2008.

113. Li, X.; Grace, J.; Lim, C.; Watkinson, A.; Chen, H.; Kim, J. Biomass gasification in a circulating fluidized bed. Biomass Bioenergy 2004, 26, 171-193. [CrossRef]

114. Corella, J.; Sanz, A. Modeling circulating fluidized bed biomass gasifiers. A pseudo-rigorous model for stationary state. Fuel Process. Technol. 2005, 86, 1021-1053. [CrossRef]

115. Sanz, A.; Corella, J. Modeling circulating fluidized bed biomass gasifiers. Results from a pseudo-rigorous 1-dimensional model for stationary state. Fuel Process. Technol. 2006, 87, 247-258. [CrossRef]

116. Helleur, R.; Popovic, N.; Ikura, M.; Stanciulescu, M.; Liu, D. Characterization and potential applications of pyrolytic char from ablative pyrolysis of used tires. J. Anal. Appl. Pyrolysis 2001, 58, 813-824. [CrossRef]

117. Jones, S.B.; Valkenburt, C.; Walton, C.W.; Elliott, D.C.; Holladay, J.E.; Stevens, D.J.; Kinchin, C.; Czernik, S. Production of Gasoline and Diesel from Biomass via Fast Pyrolysis, Hydrotreating and Hydrocracking: A Design Case; Pacific Northwest National Lab. (PNNL): Richland, WA, USA, 2009. 
118. Jones, S.B.; Snowden-Swan, L.J. Production of Gasoline and Diesel from Biomass via Fast Pyrolysis, Hydrotreating and Hydrocracking: 2012 State of Technology and Projections to 2017; Pacific Northwest National Lab. (PNNL): Richland, WA, USA, 2013.

119. Verma, M.; Godbout, S.; Brar, S.; Solomatnikova, O.; Lemay, S.; Larouche, J. Biofuels production from biomass by thermochemical conversion technologies. Int. J. Chem. Eng. 2012, 2012, 542426. [CrossRef]

120. Nam, H.; Capareda, S.C.; Ashwath, N.; Kongkasawan, J. Experimental investigation of pyrolysis of rice straw using bench-scale auger, batch and fluidized bed reactors. Energy 2015, 93, 2384-2394. [CrossRef]

121. Phan, B.M.Q.; Duong, L.T.; Nguyen, V.D.; Tran, T.B.; Nguyen, M.H.H.; Nguyen, L.H.; Nguyen, D.A.; Luu, L.C. Evaluation of the production potential of bio-oil from vietnamese biomass resources by fast pyrolysis. Biomass Bioenergy 2014, 62, 74-81. [CrossRef]

122. Montoya, J.I.; Valdés, C.; Chejne, F.; Gómez, C.A.; Blanco, A.; Marrugo, G.; Osorio, J.; Castillo, E.; Aristóbulo, J.; Acero, J. Bio-oil production from Colombian bagasse by fast pyrolysis in a fluidized bed: An experimental study. J. Anal. Appl. Pyrolysis 2015, 112, 379-387. [CrossRef]

123. Boateng, A.A.; Daugaard, D.E.; Goldberg, N.M.; Hicks, K.B. Bench-scale fluidized-bed pyrolysis of switchgrass for bio-oil production. Ind. Eng. Chem. Res. 2007, 46, 1891-1897. [CrossRef]

124. Greenhalf, C.E.; Nowakowski, D.J.; Harms, A.B.; Titiloye, J.O.; Bridgwater, A.V. A comparative study of straw, perennial grasses and hardwoods in terms of fast pyrolysis products. Fuel 2013, 108, 216-230. [CrossRef]

125. Scott, D.S.; Majerski, P.; Piskorz, J.; Radlein, D. A second look at fast pyrolysis of biomass-The RTI process. J. Anal. Appl. Pyrolysis 1999, 51, 23-37. [CrossRef]

126. Tsai, W.T.; Lee, M.K.; Chang, Y.M. Fast pyrolysis of rice husk: Product yields and compositions. Bioresour. Technol. 2007, 98, 22-28. [CrossRef] [PubMed]

127. Garcia-Perez, M.; Chaala, A.; Roy, C. Vacuum pyrolysis of sugarcane bagasse. J. Anal. Appl. Pyrolysis 2002, 65, 111-136. [CrossRef]

128. Garcia-Nunez, J.A.; Pelaez-Samaniego, M.R.; Garcia-Perez, M.E.; Fonts, I.; Abrego, J.; Westerhof, R.J.M.; Garcia-Perez, M. Historical developments of pyrolysis reactors: A review. Energy Fuels 2017, 31, 5751-5775. [CrossRef]

129. Le Brech, Y.; Jia, L.; Cissé, S.; Mauviel, G.; Brosse, N.; Dufour, A. Mechanisms of biomass pyrolysis studied by combining a fixed bed reactor with advanced gas analysis. J. Anal. Appl. Pyrolysis 2016, 117, 334-346. [CrossRef]

130. Xu, Y.; Wang, T.; Ma, L.; Zhang, Q.; Chen, G. Technology of bio-oil preparation by vacuum pyrolysis of pine straw. Trans. Chin. Soc. Agric. Eng. 2013, 29, 196-201.

131. Schulzke, T.; Conrad, S.; Westermeyer, J. Fractionation of flash pyrolysis condensates by staged condensation. Biomass Bioenergy 2016, 95, 287-295. [CrossRef]

132. Henrich, E.; Dahmen, N.; Weirich, F.; Reimert, R.; Kornmayer, C. Fast pyrolysis of lignocellulosics in a twin screw mixer reactor. Fuel Process. Technol. 2016, 143, 151-161. [CrossRef]

133. Amutio, M.; Lopez, G.; Alvarez, J.; Olazar, M.; Bilbao, J. Fast pyrolysis of eucalyptus waste in a conical spouted bed reactor. Bioresour. Technol. 2015, 194, 225-232. [CrossRef] [PubMed]

134. Alvarez, J.; Lopez, G.; Amutio, M.; Bilbao, J.; Olazar, M. Bio-oil production from rice husk fast pyrolysis in a conical spouted bed reactor. Fuel 2014, 128, 162-169. [CrossRef]

135. Garcì-Pérez, M.; Chaala, A.; Pakdel, H.; Kretschmer, D.; Roy, C. Vacuum pyrolysis of softwood and hardwood biomass: Comparison between product yields and bio-oil properties. J. Anal. Appl. Pyrolysis 2007, 78, 104-116. [CrossRef]

136. Sanginés, P.; Domínguez, M.P.; Sánchez, F.; Miguel, G.S. Slow pyrolysis of olive stones in a rotary kiln: Chemical and energy characterization of solid, gas, and condensable products. J. Renew. Sustain. Energy 2015, 7, 043103. [CrossRef]

137. Mohanty, A.K.; Misra, M.; Drzal, L. Sustainable bio-composites from renewable resources: Opportunities and challenges in the green materials world. J. Polym. Environ. 2002, 10, 19-26. [CrossRef]

138. Rogers, J.; Brammer, J. Estimation of the production cost of fast pyrolysis bio-oil. Biomass Bioenergy 2012, 36, 208-217. [CrossRef]

139. Lora, E.; Andrade, R. Biomass as energy source in brazil. Renew. Sustain. Energy Rev. 2009, 13, 777-788. [CrossRef]

140. Jackson, T. Material Concerns: Pollution, Profit and Quality of Life; Routledge: Abingdon-on-Thames, UK, 2013. 
141. Demirbas, M.F.; Balat, M.; Balat, H. Potential contribution of biomass to the sustainable energy development. Energy Convers. Manag. 2009, 50, 1746-1760. [CrossRef]

142. Saxena, R.; Adhikari, D.; Goyal, H. Biomass-based energy fuel through biochemical routes: A review. Renew. Sustain. Energy Rev. 2009, 13, 167-178. [CrossRef]

143. Hill, J. Environmental costs and benefits of transportation biofuel production from food-and lignocellulose-based energy crops: A review. In Sustainable Agriculture; Springer: New York, NY, USA, 2009; pp. 125-139.

144. Brick, S.; Lyutse, S. Biochar: Assessing the Promise and Risks to Guide Us Policy; NRDC Issue Paper; Natural Resources Defense Council: New York, NY, USA, 2010.

145. Calonaci, M.; Grana, R.; Barker Hemings, E.; Bozzano, G.; Dente, M.; Ranzi, E. Comprehensive kinetic modeling study of bio-oil formation from fast pyrolysis of biomass. Energy Fuels 2010, 24, 5727-5734. [CrossRef]

146. Ahmad, M.; Rajapaksha, A.U.; Lim, J.E.; Zhang, M.; Bolan, N.; Mohan, D.; Vithanage, M.; Lee, S.S.; Ok, Y.S. Biochar as a sorbent for contaminant management in soil and water: A review. Chemosphere 2014, 99, 19-33. [CrossRef] [PubMed]

147. Hornung, A. Transformation of Biomass: Theory to Practice; John Wiley \& Sons: Hoboken, NJ, USA, 2014.

148. Sattar, A.; Leeke, G.A.; Hornung, A.; Wood, J. Steam gasification of rapeseed, wood, sewage sludge and miscanthus biochars for the production of a hydrogen-rich syngas. Biomass Bioenergy 2014, 69, 276-286. [CrossRef]

149. Hornung, A.; Apfelbacher, A. Thermal Treatment of Biomass. U.S. Patent No. 8,835,704, 16 September 2014.

150. Brown, T.R.; Wright, M.M.; Brown, R.C. Estimating profitability of two biochar production scenarios: Slow pyrolysis vs. fast pyrolysis. Biofuels Bioprod. Biorefin. 2011, 5, 54-68. [CrossRef]

151. Vamvuka, D. Bio-oil, solid and gaseous biofuels from biomass pyrolysis processes-An overview. Int. J. Energy Res. 2011, 35, 835-862. [CrossRef]

152. Sanna, A. Advanced biofuels from thermochemical processing of sustainable biomass in Europe. BioEnergy Res. 2014, 7, 36-47. [CrossRef]

153. Rasul, M.; Jahirul, M.I. Recent Developments in Biomass Pyrolysis for Bio-Fuel Production: Its Potential for Commercial Applications; Central Queensland University, Centre for Plant and Water Science, Faculty of Sciences, Engineering and Health: Norman Gardens, Ausralia, 2012.

154. Brown, D.; Rowe, A.; Wild, P. A techno-economic analysis of using mobile distributed pyrolysis facilities to deliver a forest residue resource. Bioresour. Technol. 2013, 150, 367-376. [CrossRef] [PubMed]

155. Brown, D. Using Mobile Distributed Pyrolysis Facilities to Deliver a Forest Residue Resource for Bio-Fuel Production. Ph.D. Thesis, University of Victoria, Victoria, BC, Canada, 2013.

156. Li, D.; Briens, C.; Berruti, F. Improved lignin pyrolysis for phenolics production in a bubbling bed reactor-effect of bed materials. Bioresour. Technol. 2015, 189, 7-14. [CrossRef] [PubMed]

157. Babu, B.; Chaurasia, A. Pyrolysis of biomass: Improved models for simultaneous kinetics and transport of heat, mass and momentum. Energy Convers. Manag. 2004, 45, 1297-1327. [CrossRef]

158. Burton, A.; Wu, H. Mechanistic investigation into bed agglomeration during biomass fast pyrolysis in a fluidized-bed reactor. Energy Fuels 2012, 26, 6979-6987. [CrossRef]

159. Burton, A.H. Bed Agglomeration during Biomass Fast Pyrolysis in a Fluidised Bed Reactor. Ph.D. Thesis, Curtin University, Bentley, Australia, 2016.

160. Lin, C.-L.; Peng, T.-H.; Wang, W.-J. Effect of particle size distribution on agglomeration/defluidization during fluidized bed combustion. Powder Technol. 2011, 207, 290-295. [CrossRef]

161. Carrier, M.; Müller, N.; Grandon, H.; Segura, C.; Wilkomirsky, I.; Berg, A. Depolymerization of acetosolv lignin through in-situ catalytic fast pyrolysis. Available online: https:/ / publicaciones.udt.cl/pub/depolymerizationof-acetosolv-lignin-through-in-situ-catalytic-fast-pyrolysis / (accessed on 9 November 2018).

162. Babu, B.; Chaurasia, A. Modeling for pyrolysis of solid particle: Kinetics and heat transfer effects. Energy Convers. Manag. 2003, 44, 2251-2275. [CrossRef]

163. Solantausta, Y.; Lehto, J.; Oasmaa, A.; Kjäldman, L. Status of fast pyrolysis bio-oil technologies. In Proceedings of the 21st European Biomass Conference and Exhibition (EUBCE 2013), Copenhagen, Denmark, 3-7 June 2013.

164. Babu, B.; Chaurasia, A. Dominant design variables in pyrolysis of biomass particles of different geometries in thermally thick regime. Chem. Eng. Sci. 2004, 59, 611-622. [CrossRef] 
165. Babu, B.; Chaurasia, A. Heat transfer and kinetics in the pyrolysis of shrinking biomass particle. Chem. Eng. Sci. 2004, 59, 1999-2012. [CrossRef]

166. Thunman, H.; Niklasson, F.; Johnsson, F.; Leckner, B. Composition of volatile gases and thermochemical properties of wood for modeling of fixed or fluidized beds. Energy Fuels 2001, 15, 1488-1497. [CrossRef]

167. Johansson, R.; Andersson, K.; Leckner, B.; Thunman, H. Models for gaseous radiative heat transfer applied to oxy-fuel conditions in boilers. Int. J. Heat Mass Transf. 2010, 53, 220-230. [CrossRef]

168. Boulard, D.C. Bio-oil: The New Crude; Ensyn RTPTM Bio-Refinery: Concord, NH, USA, 2002.

169. Brown, D. Continuous ablative regenerator system. In Proceedings of the 2nd EU-Canada Workshop on Thermal Biomass Processing, 1996; CPL Press: Newbury, UK, 1996; pp. 96-100.

170. Bridgewater, A.V.; Hogan, E.N. Bio-Oil Production \& Utilisation: Proceedings of the 2nd EU-Canada Workshop on Thermal Biomass Processing; CPL Scientific Information Services Ltd.: Newbury, UK, 1996.

171. Babu, B.; Chaurasia, A. Optimization of pyrolysis of biomass using differential evolution approach. In Proceedings of the Second International Conference on Computational Intelligence, Robotics, and Autonomous Systems (CIRAS-2003), Singapore, 15-18 December 2003.

172. Thunman, H.; Leckner, B. Thermal conductivity of wood-Models for different stages of combustion. Biomass Bioenergy 2002, 23, 47-54. [CrossRef]

173. Thunman, H.; Davidsson, K.; Leckner, B. Separation of drying and devolatilization during conversion of solid fuels. Combust. Flame 2004, 137, 242-250. [CrossRef]

174. Niklasson, F.; Thunman, H.; Johnsson, F.; Leckner, B. Estimation of solids mixing in a fluidized-bed combustor. Ind. Eng. Chem. Res. 2002, 41, 4663-4673. [CrossRef]

(C) 2018 by the authors. Licensee MDPI, Basel, Switzerland. This article is an open access article distributed under the terms and conditions of the Creative Commons Attribution (CC BY) license (http:/ / creativecommons.org/licenses/by/4.0/). 